\title{
Masahiko AsAmI: A Constitutional Anthropological Study of the Inhabitants of Suhō District, Yamaguchi Prefecture, Japan
}

\section{周防地方住民の体質人類学的研究}

\author{
日本医大衐生学教室（指算 古屋芳维教授）
}

浅 見 正 彥

\section{I 周防国及び測定地の沿革}

古屋教室では， 30 数年来国内の 56 地方に 扣ける土着住民の体質人類学的研究を行つて 来たが，本研究はこの一環として，山口県の 東南部周防地方のうち, 比較的他地方との人 種的交流の少い都濃郡鹿野町を中心とした住 民の生体測定を行い，これを他地方人と比較 検討したものである。

古事記等の所伝に従えば，第 10 代の崇神天 皇の時, 阿岐国造の同祖金波佐彦の孫豊玉根 彦命を与之岐国造に任ぜられたといわれ，防 長 (周防長門) の地は，ようやく大和朝廷の 勢力下に入つたようである.ついで第 12 代の 景行天皇, 第 13 代の成務天皇の時熊襲が叛し た无め征伐の軍が再三進められているが，そ れによつて海岸沿いの地は開発されても, 山 間部にある 都濃郡一帯には未だ及ばなかつた と思われる。第 15 代の応神天皇の時, 茨城国 造の同祖加米之意美を周防国造に任じ，つい で第 16 代の德天皇の時, 紀臣の同祖都怒足 尼の児田島足尼を都怒国造に 定めたと伝えて いる.このころまでに周防の奥地も，ようゃ く開かれたのであろう．第 36 代の孝德天皇の 大化 2 年, それまで国造が世郦私有した土地 人民を，ことごとく公地とし，地方の行政区 画として，新らしく国都里の制を設けたが， 大島・都怒・周芳・与之岐の 四国造の 地は併 せて周芳の国とされ，国府を佐婆（防府市） に置いた。のち奈良時代になつて，周芳の字
を周防に 改めたが，第 42 代の 文武天皇の元 年，周防の国が饑饉に見舞われたので，免税 賑給を図つたと見えるのも，国吏の上では初 見である。

鹿野町は, 徳山の北七里, 大潮川の水源の 地で, 中国山脈東辺, 叔地山系が西走する衝 に山たり，今日都濃郡にぞくする。四囲は， 千米級の山に囲繞され，特に北方の島根県境 は, 周防の屋根と称されて, 標高 320 米の鹿 野盈地の中心地で山る。地穀の構成は, 大部 分火成岩で, 古生代の石炭紀から 2 畳紀にか けての地層で岗り，いわゆる山口变成岩類と 山口㬝郡乞呼ばれて，秩父系に属するもの， 中世代の白亚紀の 花崗岩及び 古第 3 紀層の蛇 紋岩等とから成つている。都濃は拉く都乃又 は都怒に作り，角国の内であつた。紀角宿䅘 が住んでいたので，この名が起つたともいわ れるが，国郡里が設けた時，角国の旧域は， 都濃, 佐波, 吉森の三郡に分けられて, 周防 に合併せられたという。国造本紀には, 「都怒 国造難汝寒津朝, 紀臣同祖, 都怒足尼見, 田 島足尼定賜」とあり, 都怒足尼の事は前述し たように記紀にも見えている。 又新撥姓氏録 には, 「角朝臣, 紀朝臣同祖, 紀角宿螎く後 世」と岁り, 紀角宿霞の後裔は, 古代前期に, 今の佐波郡の辺を根拠にした豪族であつた。 とすれば都濃は，紀角宿禰によつて開かれた ように考兄られるが，雄略天皇紀によると， 紀角宿䅘は, 新羅征伐の功によつて, この地 


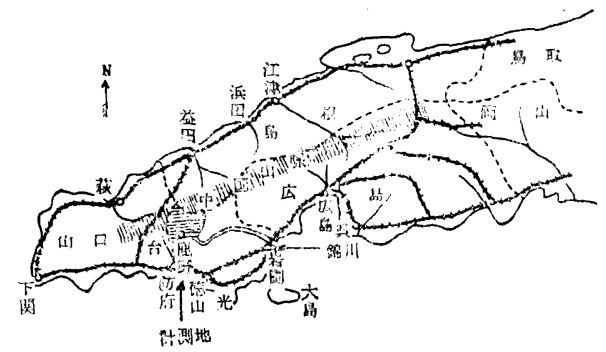

第 1 図

を賜わつたと伝えている，すなわち大和朝廷 の勢力がこの地に及んだ結果，天皇に従う紀 角宿穪は，この地に定着し，その後裔は豪族 となつてこの一帯を支配したもののようであ る、いずれにしても，都浱の地にはどのよう な先住民が住んでいたか明らかではないが， 大和朝廷が全国統一を完成した四世紀の半ば ごろまでに，その勢力下に入り，古代前期に

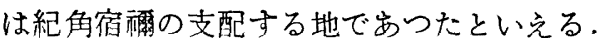

古代の後期に, 周防の地には, 多くの荘園 が開かれ，或いは東大寺大仏殿を復興した重 源などの僧によつて，文化的にも開発され， 瀬戸内海の交通が盛んになるにつれて，しだ いに意義を加光ていた，古代の末期，源平の 戦があつた 後平家の残党は多数この地方にか くれ，奥地を開拓して住みついたと伝兄，近 郷に，平家に縁のある地名や山名が多数残つ ている，降つて戦国時代には，大内・陶・毛 利に支配されたが，とくに大内氏のころは， その中心地山口は，小京都といわれて中央の 人士が来往し，又，日明貿易の結果として外国 人の来航する者が少くなかつた。かくして山 口の地は単に城下町としてばかりでなく，西 国文化の中心として栄光たことは，周防の歴 史を考光る上で忘れてはならないことである。

今回計測を行つた鹿野町一帯，すなわら周 防山間部について推察すれば，山陽道島田川 （現在山口県光市）を遡つて，三瀬川，根笠を 発見し，更に登つて高原地区を拓き，狩猟や 川漁など扎しながら土着したが，又は岩国海 岸から錦川を邀り，高山地帯に達して，農耕
地を開墾したか，或いは山陰地方の島根県側 から中国山脈を越えて入つて来たなどの道が 考えら礼る。

とこうで今日この地方の神社の神楽は，多 分に出雲系の影響を受けて招り，道は峠を越 总ても，山陰侧の方が便利で山る。したがつ て, 鹿野町一帯は, 山陽, 山陰の両方の影響 を受けていたと思考せられるのである。

本調查は上述の 周防山間部の 中心地鹿野町 を中心に行つたが，文献の示唆にとらわれず， この地方住民の体質人類学的特徴を明らかに し，可能ならばそれがどの程度に歷史的関倸 を反映しているかを見ようとしたものである。

\section{II 計測条件と項目及び計測法}

この計測の目的からして，最近の寄留者及 び一見してあきらかな体質異常者や一定不動 の姿勢を保つていられぬ者を除外し，いわゆ るこの土地の「地付の出」で，両親は勿論の こと，祖父母，曾祖父母にいたるまで三代以 上にわたつてこの地方の出身者に限つて測定 した。これは発育途上の少年や老化現象の括 きつつある年令をのぞき，満 20 才より 50 才 までの成年男子を兄らんで測定した。その人 員は565 名である。このほか 325 名の成年女 子も山わせて測定したが，他地方人との比較 検討には，成年男子の測定值のみを使用した。 体型比較の基準として使用した諸測度は，古 屋教室で古くから採用しているものに限つた。 すなわち， R. Martin 及びその他多くの体質 人類学者の使用した形質種目から，13型質を 直接に，3型質を間接に測定した．又これよ り 11 種の比率と指数を算出し，計 27 項目に ついて比較分折し検討した．その 27 項目を次 にあげる。

○直接測定項目 (13)
1. 身
長
2. 耳 珠 高
5. 中指尖端高
3. 胸骨上椽高
6. 晹骨前上棘高
4. 肩 峰高
7. 肩少
8. 頭最大長 

9. 頭最大巾
12. 下頭角巾
10. 最小前頭巾
13. 形態顔面高
11. 顴骨弓 巾

○間接測定項目 (3)
14. 耳頭高 $=$ 身長 $-耳$ 珠高
15. 全上肢長 $=$ 肩峰高一中指尖端高
16. 全下肢長 $=$ 腸骨前上棘高一身長により 一定数

○比及び指数（11）

17. 比上肢長 $=\frac{\text { 全上肢長 }}{\text { 身 長 }} \times 100$

18. 比肩巾 $=\frac{\text { 肩巾 }}{\text { 身長 }} \times 100$

19. 比頭長 $=\frac{\text { 頭最大長 }}{\text { 身 長 }} \times 100$

20. 頭長巾指数 $=\frac{\text { 頭最大巾 }}{\text { 頚最大長 }} \times 100$

21. 頭長耳頭高指数 $=\frac{\text { 耳頭高 }}{\text { 頭最大長 }} \times 100$

22. 頭巾耳頭高指数 $=\frac{\text { 耳頭高 }}{\text { 頭最大巾 }} \times 100$

23. 頭巾前頭巾指数 $=\frac{\text { 最小前頭巾 }}{\text { 頭最大巾 }} \times 100$

24. 頭巾顴骨弓巾指数 $=-\frac{\text { 顴骨弓巾 }}{\text { 頭最大巾 }} \times 100$

25. 顴骨弓巾前頭巾指数 $=\frac{\text { 最小前頭巾 }}{\text { 顴骨弓ウ }} \times 100$

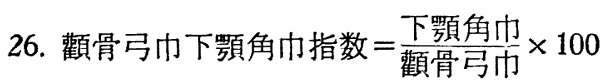

27. 形態顔面指数 $=\frac{\text { 形態顔面高 }}{\text { 顴骨弓号 }} \times 100$

数值取扱法及び計算法は古屋によつた。 そ のうち主な記号, 計算法は下記の通りである。
1. 人 員 $\mathrm{N}$
2. 算術平均 $\mathrm{M}$
3. 標準偏差 $\sigma$
4. 変異係数. $\mathrm{V}$
5. $\mathrm{m}, \mathrm{M}$ の平均誤差
6. 型差（T.D）及びその平均誤差 $\mathrm{m}$ (T.D)

$$
\begin{aligned}
\text { T.D } & \pm \mathrm{m}(\mathrm{T} . \mathrm{D})=10\left(\frac{1}{\sigma_{1}}+\frac{1}{\sigma_{2}}\right)\left(\mathrm{M}_{1} \sim \mathrm{M}_{2}\right) \\
& \pm 10\left(\frac{1}{\sigma_{1}}+\frac{1}{\sigma_{2}}\right) v^{\prime} \overline{\mathrm{m}_{1}^{2}+\mathrm{m}_{2}^{2}}
\end{aligned}
$$

7. 平均型差 (M.T.D) 及びその平均䛊差 $\mathrm{m}$

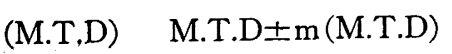

$$
\begin{aligned}
& =\frac{\Sigma\left(\frac{20}{\mathrm{~V}_{1}+\mathrm{V}_{2}}\left(\frac{1}{\sigma_{1}}+\frac{1}{\sigma_{2}}\right)\left(\mathrm{M}_{1} \sim \mathrm{M}_{2}\right)\right)}{\Sigma\left(\frac{2}{\mathrm{~V}_{1}+\mathrm{V}_{2}}\right)} \\
& \pm \frac{\Sigma\left(\frac{20}{\mathrm{~V}_{1}+\mathrm{V}_{2}}\left(\frac{1}{\sigma_{1}}+\frac{1}{\sigma_{2}}\right) \overline{\mathrm{m}_{1}^{2}+\mathrm{m}_{2}^{2}}\right)}{\Sigma\left(\frac{2}{\mathrm{~V}_{1}+\mathrm{V}_{2}}\right)}
\end{aligned}
$$

（6. 及び 7. は古屋の修正による）

\section{III軀幹四肢に関する研究成績}

軀幹四肢に関する 測定成績を一括すると次 の第 1 表の様になる .

1. 身長

身長は昔より人類形質の一指標として重ん じられている. しかし, 生活環境により除々 に平均值が変化することも周知の事実である。 だが身長は無限に変化するものではなく，日 本人なら日本人としての一定の限界が岕る。 そこに身長の人類形質としての意義がある。

\begin{tabular}{|c|c|c|c|c|}
\hline 形 & 質 & $\mathrm{M} \pm \mathrm{m}$ & $\sigma$ & V \\
\hline 身 & n) 長 & $159.98 \pm 0.22$ & 5.32 & 3.33 \\
\hline 耳 & n) 高 & $146.92 \pm 0.22$ & 5.27 & 3.59 \\
\hline 胸 骨 & : 椾) & $130.92 \pm 0.22$ & 5.30 & 4.04 \\
\hline 肩 & m) 高 & $132.50 \pm 0.22$ & 5.20 & 3.92 \\
\hline 中 指 & $\begin{array}{l}\text { (端高 } \\
\text { m) }\end{array}$ & $60.83 \pm 0.16$ & 3.86 & 6.35 \\
\hline 全 上 & $\begin{array}{l}\text { 肢 長 } \\
\text { m) }\end{array}$ & $71.73 \pm 0.13$ & 3.12 & 4.35 \\
\hline 比 & $\begin{array}{l}\text { 肢 } \\
6)\end{array}$ & $44.22 \pm 0.08$ & 1.96 & 4.43 \\
\hline 腸 骨 & 上) & $90.65 \pm 0.19$ & 4.48 & 4.89 \\
\hline 全 下 & $\begin{array}{l}\text { 肢 } \\
\text { m) }\end{array}$ & $87.21 \pm 0.16$ & 3.89 & 4.46 \\
\hline 育 & m） 幅 & $36.22 \pm 0.09$ & 2.11 & 5.99 \\
\hline 比 & f) & $21.98 \pm 0.07$ & 1.55 & 7.05 \\
\hline
\end{tabular}
また，他の計測に比較して，变異係数 (V)

第 1 表 軀幹四肢の計測値及び指数值 （周防地方人 $\mathrm{N}=565$ ) 
が小さく人類形質の価值は大きいと考学られ る。

周防地方人の身長の平均値は $159.98 \mathrm{~cm}$ で, 予想外に小さく，生体測定班計測の，日本人 男子平均 $160.24 \mathrm{~cm}$ より小さい。周防人女子 は $147.04 \mathrm{~cm}$ である。

第2 表の Martin による身長分類表を見て も小の部に $51.49 \%$ 入り，日本人としても中

第 2 表 身長分類表（Martin による）

\begin{tabular}{|c|c|c|c|c|c|c|}
\hline 類 & 甚小 & 小 & 中の下 & 中 & 中の & 高 \\
\hline \multirow[b]{2}{*}{${ }^{\text {身 }}(\mathrm{cm})^{\text {長 }}$} & 130.0 & 150.0 & 160.0 & 164.0 & 166.0 & 170.0 \\
\hline & $\widetilde{149.9}$ & $\widetilde{159.9}$ & $\widetilde{\pi}$ & $\widetilde{166.9}$ & $\widetilde{169.9}$ & $\sim$ \\
\hline & $\%$ & & & & $\%$ & \\
\hline 防 & 6.51 & 51.49 & 19.01 & 13.41 & 7.28 & 2.30 \\
\hline 幡 & 0.20 & 13.44 & 26.09 & 22.53 & 20.16 & 17.58 \\
\hline 中 & 2.42 & 36.19 & 29.40 & 16.48 & 9.53 & 3.52 \\
\hline 高 千 穗 & 3.88 & 47.47 & 26.22 & 14.56 & 4.27 & 3.30 \\
\hline 姶 & 1.76 & 36.27 & 27.50 & 18.50 & 9.25 & 6.32 \\
\hline 磨 & 3.17 & 34.45 & 24.21 & 17.32 & 12.10 & 8.75 \\
\hline 䩹 & 5.12 & 41.93 & 26.97 & 14.96 & 6.89 & 4.13 \\
\hline 雲 & 2.35 & 41.88 & 26.33 & 15.61 & 8.24 & 5.56 \\
\hline 巨 & 5.53 & 42.99 & 27.27 & 14.63 & 7.51 & 2.77 \\
\hline 信州上伊那 & 1.80 & 39.00 & 28.80 & 15.00 & 11.40 & 4.00 \\
\hline 庄 内 & 3.59 & 42.58 & 29.85 & 13.70 & 7.18 & 3.10 \\
\hline 信 州飯 田 & 1.00 & 33.50 & 25.50 & 18.50 & 15.00 & 6.50 \\
\hline 加賀平地 & 3.01 & 44.15 & 27.54 & 14.40 & 7.38 & 3.53 \\
\hline 大 和 & 0.55 & 35.98 & 28.73 & 16.51 & 10.84 & 7.39 \\
\hline 立 & 3.33 & 47.00 & 26.50 & 13.78 & 5.50 & 3.89 \\
\hline 能登南部 & 4.13 & 48.32 & 26.86 & 10.79 & 6.92 & 2.98 \\
\hline 信州安虽 & 1.70 & 36.49 & 29.49 & 17.58 & 9.07 & 5.67 \\
\hline 三 宅 島 & 4.00 & 32.80 & 31.20 & 17.60 & 8.80 & 5.60 \\
\hline 八丈島 & 1.79 & 45.90 & 28.46 & 14.18 & 6.67 & 3.08 \\
\hline 加賀山地 & 3.89 & 51.11 & 27.22 & 11.39 & 3.89 & 2.50 \\
\hline 越後東蒲原 & 3.99 & 56.33 & 22.53 & 12.44 & 2.82 & 1.89 \\
\hline 磐 & 1.89 & 48.67 & 24.81 & 12.88 & 7.21 & 4.55 \\
\hline 岩代熱海 & 3.67 & 50.53 & 25.70 & 13.60 & 3.50 & 2.97 \\
\hline 千葉中部 & 0.55 & 32.29 & 28.26 & 19.08 & 13.21 & 6.61 \\
\hline 北部 信 州 & 0.50 & 26.41 & 29.91 & 19,76 & 14.28 & 9.14 \\
\hline 奥 能 登 & 5.52 & 52.14 & 23.97 & 11.29 & 3.96 & 3.13 \\
\hline \pm & 0.00 & 42.00 & 33.33 & 14.67 & 8.67 & 1.33 \\
\hline 中 & 3.88 & 60.00 & 21.66 & 7.77 & 3.88 & 2.77 \\
\hline 飛 & 4.11 & 57.78 & 21.92 & 9.96 & 5.11 & 1.12 \\
\hline 埼玉東部 & 3.80 & 40.00 & 23.80 & 15.20 & 7.20 & 5.00 \\
\hline
\end{tabular}

以下の身長である。全般的にその分布状態は， 加賀山地，奥能登，岩代熱海人に類似してい る. 身長そのものでは，土佐人の $159.77 \mathrm{~cm}$ 加賀平地人の $160.28 \mathrm{~cm}$ に近い，女子の 147.04 $\mathrm{cm}$ も小さい部に入る. 古屋修正の型差公式 により，身長の型差（T.D.）を算出したが， この型差による他地方人との 親近度を見ると 第 3 表のよ 5 , 土佐人 T.D. 0.79 , 高千穂人 の 0.89 , 加賀平地人, 能登南部人の 1.10 など に近親度が強い。地域的には近い因幡人と T.D. 12.99 と云う様に近親度がうすいことは 面白いことである．出雲人，備中人と 3.52 ,

第 3 表 身長に於ける周防地方と 他地方人との型差

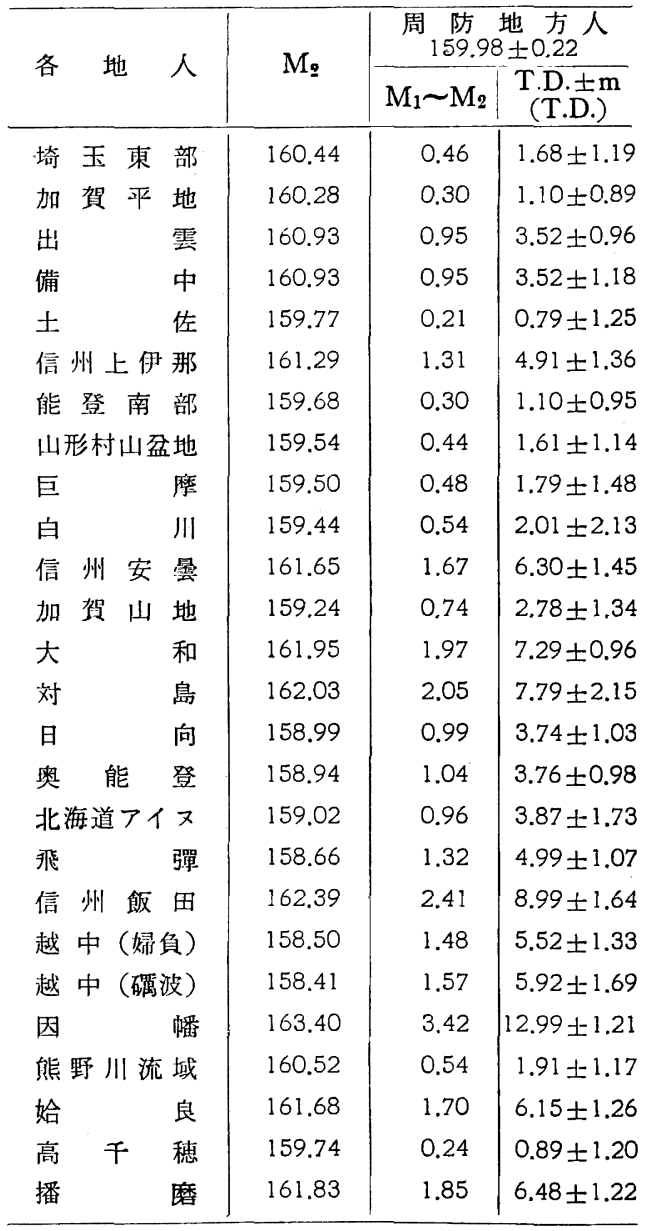


大和人と 7.29 , 播磨人と 6.48 と云う関係が出 たが，身長に関しては，山まり近親度はこく ないと考えられる。

\section{2. 耳 珠 高}

耳珠高は stadiometer を使用し被計測者の右 乳頭線に立て, 右側耳珠点と踏台との垂直 距離を計測した。耳珠高は計測值そのものよ りも，身長より耳珠高を引き，耳頭高の間接算 出法のための測度として意味がある。周防人 の平均值は $146.92 \pm 0.22$ を示している. 大和， 出雲, 播磨, 備中人の, $148.87 \mathrm{~cm}, 148.23 \mathrm{~cm}$, $148.70 \mathrm{~cm}, 148.67 \mathrm{~cm}$ に比して小である。

\section{3. 肩 峰 高}

肩峰高は stadiometer により，左手指にて 被計測者の右肩の Akromion をさぐつてそ の垂直距離を測定した。周防人の平均值は $132.50 \pm 0.22$ であり, 大和人の $131.26 \mathrm{~cm}$, 出 雲人の $136.21 \mathrm{~cm}$, 備中人の $131.32 \mathrm{~cm}$, 飛弾人 の $131.19 \mathrm{~cm}$, 高千穂人の $129.80 \mathrm{~cm}$, 越中人の $129.14 \mathrm{~cm}$ より大きく, 因幡人の $134.66 \mathrm{~cm}$, ，播磨人の $135.69 \mathrm{~cm}$, 姶良人の $133.62 \mathrm{~cm}$ より 小である.

\section{4. 中指尖端高}

中指尖端高も Stadiometer で右側中指尖端 よりの垂值距離を測定した，肩峰高より中指 尖端高との差で全上肢長が 測定できるのであ るから，この測定時には上肢を移動させない 樣に注意した。周防人の平均值は $60.83 \pm 0.16$ であり，備中人の $60.52 \mathrm{~cm}$, 飛弾人の 57.47 $\mathrm{cm}$, 薩摩人の $60.71 \mathrm{~cm}$ より大きく, 大和人の $61.25 \mathrm{~cm}$, 出雲人の $61.01 \mathrm{~cm}$, 姶良人の $61,88 \mathrm{~cm}$, 高千穂人の $61.87 \mathrm{~cm}$, 播磨人の $62.52 \mathrm{~cm}$, 因幡 人の $64.45 \mathrm{~cm}$ より小さい.

\section{5. 全上肢長}

この全上肢長は，肩峰高より中指尖端高を ひいた間接測定値である，周防地方人は 71.73 $\mathrm{cm}$ で播磨, 備中, 因幡, 大和, 出雲人の $69.71 \mathrm{~cm}, 70.50 \mathrm{~cm}, 69.82 \mathrm{~cm}, 70.02 \mathrm{~cm}, 70.19 \mathrm{~cm}$ より大きい，飛弾人の $71.85 \mathrm{~cm}$, 北海道アイ ヌ人の $72.08 \mathrm{~cm}$, 櫣太アイヌ人の $72.55 \mathrm{~cm}$ よ
り小さいが，相当全上肢長が大きい值を示し ている。
6. 比上肢長

比上肢長は身長と全上肢長との比であるが， $44.22 \%$ を示し, 大和, 出雲, 播磨, 備中, 因 幡地方人の $43.25,43.64,43.07,43.62,42.36$ よ り大きい. 越中, 北海道アイヌ, 樺太アイヌ 人の $44.74,45.36,45.84$ より小さい. Iwanowski の上肢分類により，上肢長の分類を他地 方人と比較すると第 4 表の様になり，長腕に $46.50 \%$ 入り, 中腕の $32.56 \%$, 短腕の $21.39 \%$ の割合になつている. この分布の傾向として は，庄内人に似ているが，日本人のなかでは 相当長腕の部に入つているといえる.

7. 腸骨前上棘高及び全下肢長

周防人の平均値は $90.65 \mathrm{~cm}$ で, 播磨人の $90.83 \mathrm{~cm}$ より小さいが，大和人, 出雲人 88.41

第 4 表 上肢分類表（此上肢長による）

\begin{tabular}{|c|c|c|c|c|}
\hline 分 & 類 & 短 & 中 & 長 \\
\hline 比 上 肢 & 長 & $\sim 42.9$ & $43.0 \sim 44.9$ & $45.0 \sim$ \\
\hline 播 & 磨 & $18.13 \%$ & $79.63 \%$ & $2.24 \%$ \\
\hline 高 & 麗 & 23.62 & 55.51 & 20.87 \\
\hline 巨 & 摩 & 25.25 & 59.68 & 15.07 \\
\hline 千 葉 中 & 部 & 19.63 & 59.45 & 20.92 \\
\hline 八 丈 & 島 & 23.85 & 61.28 & 14.87 \\
\hline 高 千 & 穂 & 58.42 & 36.04 & 5.54 \\
\hline 日 & 立 & 35.00 & 55.33 & 9.67 \\
\hline 岩 代 熱 & 海 & 18.88 & 51.93 & 29.19 \\
\hline 艁 & 城 & 17.05 & 51.13 & 31.82 \\
\hline 信州上伊 & 那 & 25.00 & 58.50 & 16.50 \\
\hline 北 部 信 & 州 & 26.74 & 61.96 & 11.30 \\
\hline 出 & 雲 & 27.01 & 62.80 & 10.19 \\
\hline 三 宅 & 島 & 16.00 & 64.80 & 19.20 \\
\hline 信 州 飯 & 田 & 35.50 & 58.00 & 6.50 \\
\hline 信 州 安 & 舉 & 39.32 & 57.09 & 3.59 \\
\hline 大 & 和 & 41.71 & 52.28 & 6.01 \\
\hline 庄 & 内 & 10.77 & 42.74 & 46.49 \\
\hline 埼 玉 東 & 部 & 28.43 & 59.36 & 12.21 \\
\hline 因 & 幡 & 57.71 & 37.75 & 14.54 \\
\hline 備 & 中 & 22.78 & 57.19 & 20.03 \\
\hline 周 & 防 & 21.39 & 32.56 & 46.05 \\
\hline
\end{tabular}


$\mathrm{cm}, 87.70 \mathrm{~cm}$ より大きい。

全下肢長は人種によつて差異が㟧るここは 周知の事実である。日本人は明治以降生活環 境の改善により, 身長の增大が認められるが, その原因としては下肢長の增長があげられる。 これは米国生れの 日本人二世の 例によつてる 証明できることである。しかし，全下肢長を 生体にて正確に則定することは，今日不可能 で山るから，“腸骨前上棘高と聎骨上縁高の中 間値をとる場合と，腸骨前上棘高を下肢長の 代用とする場合，及び Martin の推定してい る腸骨前上棘高より身長に比例して次に示す 数値を引き，下肢長の近似值を求める場合の 三法があるが，私は第三の Martin の方法 により，下肢長を求めた。即ち，

$130 \mathrm{~cm}$ 以下の身長では $15 \mathrm{~mm}$ 引く $131 \sim 150 \mathrm{~cm}$ の身長では $20 \mathrm{~mm}$ 引く $151 \sim 165 \mathrm{~cm}$ の身長では $30 \mathrm{~mm}$ 引く $166 \sim 175 \mathrm{~cm}$ の身長では $40 \mathrm{~mm}$ 引く $170 \mathrm{~cm}$ 以上の身長では $50 \mathrm{~mm}$ 引く で山る.

周防人の全下肢長は $87.21 \mathrm{~cm}$ であり, 播磨 人の $87.48 \mathrm{~cm}$ より小さいか，三宅島，八丈 島, 村山盈地人の $84.28 \mathrm{~cm}, 83.50 \mathrm{~cm}, 83.69 \mathrm{~cm}$ より大きい。

\section{IV 頭部に関する研究成樍}

頭部に関する䘄々の計測値及び 指数値は人 種相互間の近親度を論ずるのに最も必要で重 要な価值がある。頭部に関する 9 項目の計测 値を一括して示せば次の第 5 表の樣である。

1. 頭長最大長及び頭最大巾

頭最大長及び頭最大巾は頭型及び 種々の頭 部指数を算出する基本となる重要な計測值で ある. 人類学的に価值の高い人種形質として Anders. Retius 以来多くの研究者に使用され 検討されて来た，頭最大長，頭最大巾につい ては Walcher, Boas 等の一部の反対学説, 及 び未開土人間に 於ける 風俗留懢的人意的変化 を除けば，一般には後天的影響の少い計測値
第 5 装 頭部の計湘值及び指数值 （周防地方人 $N=565$ )

\begin{tabular}{|c|c|c|c|}
\hline 形 & $M \pm m$ & $\sigma$ & V \\
\hline 頭毁大長 (mm) & $184.00 \pm 0.23$ & 5.36 & 2.91 \\
\hline 頭最大幅 (mm) & $151.70 \pm 0.22$ & 5.20 & 3.43 \\
\hline 頭 長 幅 指 数 & $82.65 \pm 0.17$ & 4.12 & 4.98 \\
\hline 恥 頭 高 $(\mathrm{mm})$ & $129.54 \pm 0.29$ & 6,85 & 5.29 \\
\hline 顽長耳頭高指数 & $70.40 \pm 0.26$ & 6.24 & 8.86 \\
\hline 顥幅耳頭高指数 & $85.25 \pm 0.26$ & 7.62 & 8.93 \\
\hline 最小前頭幅 (mm) & $125.66 \pm 0.28$ & 6.74 & 5.36 \\
\hline 頭幅 前頭 幅指数 & $82.66 \pm 0.20$ & 4.75 & 5.75 \\
\hline 比 頭 長 $(\%)$ & $11.50 \pm 0.02$ & 0.53 & 4.61 \\
\hline
\end{tabular}

とみるべきである，最近わが国に於てる頭型 が環境の変化によつてかなり動くことを証明 した学者があるが，これは場合によつて充分 ありうることである。然しそうといつてもそ の頭部計測値が 人種学的に 無意味だというの ではない，ただ頭型を数字で表わすことは困 難ではあるが，頭最大長，頭最大巾を厳密に 測定し，或は種々の指数を算出して検討する ならば，かなり正確に人種的特徴を知り得る のであつて，人種学的に重要な指標であるこ とを失わない。

周防人の測定成績は $184.00 \pm 0.22$ で, 大和, 借中，播磨，因幡の $185.06 \mathrm{~mm}, 185.21 \mathrm{~mm}$, $185.43 \mathrm{~mm}, 185.80 \mathrm{~mm}$ より小さく出雲人の $183.39 \mathrm{~mm}$, 相模平野人の $183.08 \mathrm{~mm}$ より大で あるが，古屋一門で計測した 57 地方人の中で は小さい方である。最も近似值を示している ものは，信州飯田人の $184.15 \mathrm{~mm}$ で，巨摩人 の $184.68 \mathrm{~mm}$ もこれに近い.女子は $176.40 \mathrm{~mm}$ である。

頭最大巾の平均值は $151.70 \pm 0.22$ で備中人 の $151.92 \mathrm{~mm}$, 出雲人の $152.08 \mathrm{~mm}$, 奥能登人の $151.90 \mathrm{~mm}$, 土佐人の $151.46 \mathrm{~mm}$ と近似值を示 している.女子は $147.68 \mathrm{~mm}$ で山る。

頭最大長と頭最大巾の周防人と他地方人と の型差は第 6 表及び第 7 表で示している．頭 最大長では，信州飯田人の 0.52 , 次に出雲人 
第 6 表 頭最大長に於ける周防地方人と 他地方人との型差

\begin{tabular}{|c|c|c|c|c|}
\hline \multirow{2}{*}{ 各 地 } & \multirow{2}{*}{ 人 } & \multirow{2}{*}{$\mathrm{M}_{2}$} & \multicolumn{2}{|c|}{$\begin{array}{l}\text { 周防地方 } 1 \\
184.00 \pm 0.23\end{array}$} \\
\hline & & & $\mathrm{M}_{1} \sim \mathrm{M}_{2}$ & $\begin{array}{c}\text { T.D. } \pm \mathrm{m} \\
\text { (T.D.) }\end{array}$ \\
\hline 対 & 島 & 188.66 & 4.66 & $15.10 \pm 2.42$ \\
\hline 日 & 向 & 188.63 & 4.46 & $16.02 \pm 1.98$ \\
\hline \pm & 佐 & 188.42 & 4.42 & $15.29 \pm 1.13$ \\
\hline 飛 & 彈 & 188.30 & 4.30 & $15.52 \pm 1.10$ \\
\hline 奥＼cjkstart能 & 登 & 188.10 & 4.10 & $14.88 \pm 1.21$ \\
\hline 加賀平 & 地 & 188.00 & 4.00 & $13.96 \pm 0.94$ \\
\hline 山形村山盆 & 地 & 187.95 & 3.95 & $13.39 \pm 1.18$ \\
\hline 白 ， & 川 & 187.80 & 3.80 & $12.92 \pm 2.31$ \\
\hline 姶。 & 良 & 187.49 & 3.49 & $12.08 \pm 1.28$ \\
\hline 能 登南 & 部 & 190.20 & 6.20 & $21.90 \pm 0.97$ \\
\hline 加賀 山1 & 地 & 187.30 & 3.30 & $12.68 \pm 1.40$ \\
\hline 播 & 磨 & 185.43 & 1.43 & $4.60 \pm 1.32$ \\
\hline 高千 & 穗 & 187.58 & 3.58 & $11.46 \pm 1.28$ \\
\hline 信 州 安 & 雲 & 186.98 & 2.98 & $11.32 \pm 1.21$ \\
\hline 因 , & 幡 & 185.80 & 1.80 & $5.76 \pm 1.24$ \\
\hline 信州上伊五 & 䣂 & 185.67 & 1.67 & $5.83 \pm 1.43$ \\
\hline 越中（婦負 & & 192.00 & 8.00 & $27.92 \pm 1.35$ \\
\hline 埼玉 東 & 部 & 185.28 & 1.28 & $4.34 \pm 1.23$ \\
\hline 薉 & 中 & 185.21 & 1.21 & $4.11 \pm 1.23$ \\
\hline 大 & 和 & 185.06 & 1.06 & $3.50 \pm 0.98$ \\
\hline 巨 & 摩 & 184.68 & 0.68 & $2.51 \pm 1.50$ \\
\hline 北海道アイ & z & 195.40 & 11.40 & $40.47 \pm 1.86$ \\
\hline 信 州 飯 & 田 & 184.15 & 0.15 & $0.52 \pm 1.72$ \\
\hline 越中（碑波 & & 193.70 & 9.70 & $33.85 \pm 1.73$ \\
\hline 出 至 & 雲 & 183.39 & 0.61 & $2.19 \pm 0.99$ \\
\hline 熊野川流 & & 188.83 & 4.83 & $15.89 \pm 1.24$ \\
\hline
\end{tabular}

の 2.19 また 2.51 の巨摩人こ近親度が濃厚で少 るが, 北海道フイ マ人の 40.47 , 越中人の 33.85 及び 27.92 , 能登南部人の 21.90 とは近親度が うすい. 大和, 備中人は $3.50,4.11$ を示して いる.

頭最大巾では，奥能登の 0.78 を筆頭に鞴中 人の 0.79 , 土佐人の 0.91 , 出雲人の 1.48 など と近親度が強く, 姶良, 因幡とはいくらか近 親度が弱い。

\section{2. 頭長巾指数}

頭長巾指数は頭最大巾の頭最大長に対する 比で示される頭型の簡単な表示法で岕る。
第 7 表 頭最大幅に於ける周防地方と 他地方人との型差

\begin{tabular}{|c|c|c|c|c|}
\hline \multirow{2}{*}{ 各 } & \multirow{2}{*}{ 人 } & \multirow{2}{*}{$\mathrm{M}_{2}$} & \multicolumn{2}{|c|}{$\begin{array}{c}\text { 周防地方人 } \\
151.70 \pm 0.22\end{array}$} \\
\hline & & & $\mathrm{M}_{1} \sim \mathrm{M}_{2}$ & \begin{tabular}{|l} 
T.D. $\pm \mathrm{m}$ \\
(T.D.)
\end{tabular} \\
\hline 巨 & 摩 & $153: 20$ & $\cdot 1.50$ & $6.02 \pm 1.49$ \\
\hline 大 & 和 & 153.11 & 1.41 & $5.08 \pm 0.96$ \\
\hline 信州上伊死 & 那 ${ }^{\circ}$ & 152.96 & 1.26 & $4.94 \pm 1.36$ \\
\hline 対 & 島 & 154.26 & 2.56 & $10.73 \pm 2.07$ \\
\hline 信 州 飯 & 田 & 154.45 & 2.75 & $10.37 \pm 1.66$ \\
\hline 信 州 安 & 壆 & 152.73 & 1.03 & $4.35 \pm 1.54$ \\
\hline 播 & 穈 & 153.49 & 1.79 & $6.43 \pm 1.17$ \\
\hline 高 & 穂 & 154.49 & 2.79 & $10.04 \pm 1.23$ \\
\hline 因 & 幡 & 155.08 & 3.38 & $12.17 \pm 1.20$ \\
\hline 飛 & 彈 & 152.30 & 0.60 & $2.39 \pm 1.11$ \\
\hline 出 & 雲 & 152.08 & 0.38 & $1.48 \pm 0.99$ \\
\hline 埼 玉 東 咅 & 部 & 152.16 & 0.46 & $1.91 \pm 1.21$ \\
\hline 備 & 中 & 151.92 & 0.22 & $0.79 \pm 1.17$ \\
\hline 姶 & 良 & 155.47 & 3.77 & $13.76 \pm 1.27$ \\
\hline 奥 能 & 登 & 151.90 & 0.20 & $0.78 \pm 1.04$ \\
\hline 土 & 佐 & 151.46 & 0.24 & $0.91 \pm 1.23$ \\
\hline 山形村山盆且 & & 151.20 & 0.50 & $1.89 \pm 1.15$ \\
\hline 越中（噧波 & & 150.92 & 0.78 & $2.68 \pm 1.48$ \\
\hline 日 仰 & 向 & 150.83 & 0.87 & $3.38 \pm 1.03$ \\
\hline 加賀山其 & 地 & 150.80 & 0.90 & $3.59 \pm 1.36$ \\
\hline 能 登南 咅 & 部 & 150.70 & 1.00 & $3.92 \pm 1.00$ \\
\hline 白 & $M$ & 150.70 & 1.00 & $3.97 \pm 2.10$ \\
\hline 越中（婦負 & & 150.70 & 1.00 & $4.13 \pm 1.31$ \\
\hline 北海道アイ & & 149.30 & $2.4 Q$ & $9.77 \pm 1.75$ \\
\hline 加贺 平地 & & 149.10 & 2.60 & $10.30 \pm 0.97$ \\
\hline 熊野川流场 & & 153.62 & 1.92 & $6.91 \pm 1.22$ \\
\hline
\end{tabular}

Martin はこの指数を使用して頭型の分類をし ているが，頭型を表現するものとしては，完 全なものではないが，今日迄数多くの研究者 に使用され，他の頭部指数と共に種族差異を 示す重要な指数である. 周防人の頭長门指数 は，82.65士0.17で，古屋一門によつて測定さ れた 57 地区の平均值 81.36 に比較して 1.29 も 大きく，生体測定班の日本人平均の 81.21 よ りもはるかに大きく，短頭型に属している。 他地方と比較したものが，第 8 表の Martin の頭型分類表と，第 9 表の型差による表で山 る.女子は 83.68 である. 
第 8 表 頭長巾指数頭型分類表

\begin{tabular}{|c|c|c|c|c|c|}
\hline 頭 & 訨 & 長頭型 & 中頭型 & 短頭型 & 過短頭型 \\
\hline 頭長 巾指 & & $\sim 75.9$ & $\begin{array}{c}76.0 \\
\widetilde{80.9}\end{array}$ & $\begin{array}{c}81.0 \\
\tilde{85.4}\end{array}$ & $85.5 \sim$ \\
\hline 周 & 防 & $4.60 \%$ & $31.86 \%$ & $44.00 \%$ & $19.54 \%$ \\
\hline 请 & 中 & 6.79 & 32.15 & 36.99 & 24.07 \\
\hline 因 & 幡 & 4.55 & 26.88 & 39.13 & 29.44 \\
\hline 播 & 糜 & 6.14 & 28.31 & 41.71 & 23.84 \\
\hline 高 & 䦥 & 3.34 & 29.53 & 47.44 & 19.69 \\
\hline 巨 & 摩 & 3.94 & 29.25 & 46.64 & 20.17 \\
\hline 出 & 墨 & 2.14 & 31.64 & 45.84 & 20.38 \\
\hline 伊 & 那 & 1.69 & 26.97 & 47.00 & 24.34 \\
\hline 丈 & 島 & 1.79 & 30.00 & 46.67 & 21.54 \\
\hline 信 州 安 & 雲 & 0.57 & 43.67 & 48.20 & 7.56 \\
\hline 三 宅 & 島 & 1.60 & 42.40 & 49.60 & 6.40 \\
\hline 信州上伊 & ث 那 & 2.00 & 31.00 & 48.00 & 19.00 \\
\hline 倍 州 飯 & 田 & 1.50 & 20.00 & 45.00 & 33.50 \\
\hline 信 州 北 & 部 & 3.66 & 34.38 & 41.19 & 20.77 \\
\hline 大 & 和 & 5.25 & 31.38 & 38.82 & 24.30 \\
\hline 庄 & 内 & 3.10 & 45.35 & 40.78 & 10.77 \\
\hline 千葉 中 & 部 & 3.85 & 24.96 & 42.20 & 28.99 \\
\hline 能 & 登 & 5,47 & 49.27 & 39.96 & 5.29 \\
\hline 飛 & 彈 & 5.35 & 48.07 & 39.85 & 6.72 \\
\hline 村 山 盆 & 地 & 9.12 & 49.12 & 31.20 & 10.56 \\
\hline 千 & 悡 & 8.42 & 34.44 & 34.44 & 22.70 \\
\hline 加 贺 山 & 地 & 4.78 & 53.09 & 34.83 & 7.30 \\
\hline 岩 代 熱 & 游 & 8.92 & 45.10 & 33.04 & 12.94 \\
\hline 日. & 立 & 10.50 & 53.67 & 28.00 & 7.83 \\
\hline 加 賀 平 & “地 & 14.81 & 54.88 & 27.34 & 2.79 \\
\hline 能 登 南 & 馟 & 14.76 & 55.83 & 26.49 & 2.72 \\
\hline 船 & 城 & 18.75 & 54.74 & 22.73 & 3.79 \\
\hline & 41 & 27.65 & 54.24 & 16.48 & 1.58 \\
\hline 䡃 丙東 & 灏 & 4.72 & 33.64 & 42.03 & 19.61 \\
\hline
\end{tabular}

䎻防人の頭型分類は中頭型に $31.86 \%$ ，短頭 型に $44.00 \%$ で合部 $75.86 \%$ を示し，過短頭型 にも $19.54 \%$ ぞくして拈り，周防人は㟧きら かに短頭でも岕ることを示している。これを 他地方人と比較すれば一層岕さらかになる。

第 2 図でわかる様に 北海道アイヌ人及び 越中 人とは分数曲線が周防人と刘照的な曲線次四 いているが，出雲人とは同じ様な曲線を示し ている。 その他分類曲線の類似しているもの
第 9 表 頭長幅指数に於ける周防地方人と 他地方人との型差

\begin{tabular}{|c|c|c|c|}
\hline \multirow{2}{*}{ 各地 人 } & \multirow{2}{*}{$\mathrm{M}_{2}$} & \multicolumn{2}{|c|}{$\begin{array}{l}\text { 周 防 地方人 } \\
82.65 \pm 0.17\end{array}$} \\
\hline & & $M_{1} \sim M_{2}$ & \begin{tabular}{|c} 
T.D. $\pm \mathrm{m}$ \\
(T.D.)
\end{tabular} \\
\hline 島 & 81.85 & $0.80^{\prime}$ & $4.66 \pm 1.96$ \\
\hline 信 州 安 需 & 81.85 & 1.07 & $6.68 \pm 1.26$ \\
\hline 倩 & 82.21 & 0.44 & $1.98 \pm 1.15$ \\
\hline 埼 玉 東 部 & 82.22 & 0.43 & $2.14 \pm 1.19$ \\
\hline 因幡 & 82.47 & 0.18 & $0.83 \pm 1.17$ \\
\hline 信州上伊哪 & 82.55 & 0.10 & $0.53 \pm 3.58$ \\
\hline 磨 & 82.61 & 0.04 & $0.17 \pm 1.23$ \\
\hline 高 千 㗭 & 82.41 & 0.24 & $1.08 \pm 1.22$ \\
\hline 出 雲 & 82.67 & 0.02 & $0.10 \pm 0.99$ \\
\hline 摩 & 82.71 & 0.06 & $0.33 \pm 1.45$ \\
\hline 飛 & 80.92 & 1.73 & $9.50 \pm 1.14$ \\
\hline 大 & 82.76 & 0.11 & $0.51 \pm 0.95$ \\
\hline 奥 能 & 80.83 & 1.82 & $10.16 \pm 1.19$ \\
\hline 良 & 82.98 & 0.33 & $1.67 \pm 1.22$ \\
\hline$川$ & 80.42 & 2.23 & $10.35 \pm 1.85$ \\
\hline 山形村山盆地 & 80.51 & 2.14 & $10.89 \pm 1.15$ \\
\hline 加 贺 山地 & 80.59 & 2.11 & $11.77 \pm 1.34$ \\
\hline 土 佐 & 80.47 & 2.18 & $11.34 \pm 1.21$ \\
\hline 日向 & 79.98 & 2.67 & $13.96 \pm 1.06$ \\
\hline 信 州 饭 田 & 84.10 & 1.45 & $7.24 \pm 1.63$ \\
\hline 加 賀 山地 & 79.38 & 3.27 & $17.69 \pm 0,99$ \\
\hline 能 登 南 部 & 79.36 & 3.29 & $18.13 \pm 1.03$ \\
\hline 越中（婦負） & 78.58 & 4.07 & $23.24 \pm 1.33$ \\
\hline 越 中（彈波） & 77.92 & 4.73 & $25.54 \pm 1.59$ \\
\hline 北海道アイヌ & 76.59 & 6.06 & $36.84 \pm 1.09$ \\
\hline 熊野川流域 & 81.84 & 0.81 & $3.87 \pm 1.35$ \\
\hline
\end{tabular}
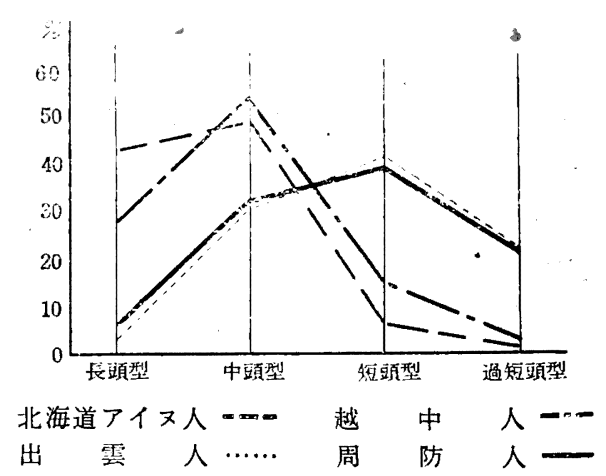

第 2 图頭長巾指数䫓型分類

に大和人，埼玉東部人，信州北部人などがあ げられる.型差では，出雲人の 0.10 播磨人の 
0.17 , 巨摩, 大和, 信州上伊那, 因幡人は全 て 1.00 以下で近親度が強い.

4. 比頭 長

頭最大長と身長との比を\%であらわしたも

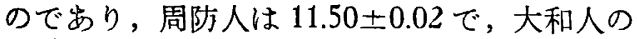
11.43 , 出雲人の 11.39 , 播磨人の 11.45 , 備中人 の 11.52 と類似して抒り，有意の差はみとめ られない。

\section{5. 耳 頭 高}

耳頭高の計測法には 直接法と間接法の 2 法 がある。即ち直接法は Stangenzirkel で，頭 頂と耳珠点との距離を直接に計測する方法で, 間接法は身長より耳珠高を引いたその差を耳

第 10 表 耳頭高に於忛る周防地方人と 他地方人との型差

\begin{tabular}{|c|c|c|c|}
\hline \multirow{2}{*}{ 各 地 人 } & \multirow{2}{*}{$\mathrm{M}_{2}$} & \multicolumn{2}{|c|}{$\begin{array}{l}\text { 周防 地方 } 人 ~ \\
129.54 \pm 0.29\end{array}$} \\
\hline & & $\mathrm{M}_{1} \sim \mathrm{M}_{2}$ & $\begin{array}{c}\text { T.D. } \pm \mathrm{m} \\
\text { (T.D.) }\end{array}$ \\
\hline 信 州 飯 & 127.68 & 1.86 & $5.17 \pm 1.68$ \\
\hline 巨 & 127.60 & 1.94 & $4.87 \pm 1.65$ \\
\hline 日 & 127.42 & 2.12 & $6.19 \pm 1.03$ \\
\hline 信 州 安 照 & 126.98 & 2.56 & $6.50 \pm 1.25$ \\
\hline 土 & 127.67 & 2.89 & $7.60 \pm 1.30$ \\
\hline 出 & 126.71 & 2.83 & $8.21 \pm 0.67$ \\
\hline 信州上伊井 & 126.37 & 3.17 & $9.29 \pm 1.38$ \\
\hline 埼玉 東 部 & 126.08 & 3.46 & $9.79 \pm 1.25$ \\
\hline 対 & 125.61 & 3.96 & $9.24 \pm 2.42$ \\
\hline 飛 & 125.60 & 3.94 & $10.64 \pm 1.09$ \\
\hline 加 賀 平 地 & 125.80 & 3.74 & $11.52 \pm 0.99$ \\
\hline 播 & 131.71 & 2.17 & $6.49 \pm 1.43$ \\
\hline 高千 & 123.85 & 5.69 & $14.62 \pm 1.25$ \\
\hline 北海道アイヌ & 125.70 & 3.84 & $11.33 \pm 1.86$ \\
\hline 姶 & 125.32 & 4.22 & $10.68 \pm 1.31$ \\
\hline 越中（婦負 & 125.30 & 4.24 & $12.51 \pm 1.32$ \\
\hline 大 & 130.91 & 1.37 & $3.56 \pm 0.96$ \\
\hline 加 賀 山 & 124.50 & 5.04 & $15.32 \pm 1.34$ \\
\hline 備 & 124.04 & 5.50 & $15.40 \pm 1.21$ \\
\hline 山形村山盆.地 & 123.68 & 5.86 & $16.00 \pm 1.16$ \\
\hline 越 中（燳波） & 123.41 & 6.13 & $18.39 \pm 1.68$ \\
\hline 因 & 122.06 & 7.48 & $18.70 \pm 1.26$ \\
\hline 能 登 南 & 123.20 & 6.34 & $20.92 \pm 1.14$ \\
\hline 奥＼cjkstart能 & 120.60 & 8.94 & $28.25 \pm 1.21$ \\
\hline 白 & 117.80 & 11.74 & $33.69 \pm 2.08$ \\
\hline 熊野川流域 & 127.67 & 1.87 & $4.81 \pm 1.25$ \\
\hline
\end{tabular}

頭高とする方法である. しかし両法とも垂直 保持が困難であるから，測定誤差が大となり 易いので，計測のさい慎重に行わねばならな いものである。私は間接法により算出した。

周防人は $129.54 \pm 0.29$ で，大和人の 130.91 $\mathrm{mm}$, 新潟東蒲原人の $130.98 \mathrm{~mm}$ ， と播磨人の $131.71 \mathrm{~mm}$ ，北朝鮮人の $132.65 \mathrm{~mm}$ と比較的近 似值を示しているが，周防人の耳頭高は古屋 一門の計測した 57 地区の耳頭高の計測值に比 して，大きい数值を示している．その他の地 方人とは相当かけはなれた数值を示し,有意の 差が認められる．第 10 表の型差に招いても同 様に大和人の T.D. 3.56 , 巨摩人の 4.87 , 熊 野川流域住民の 4.81 ぐらいが近親度がいくら かむると云えるのみで, 白川人の 33.69 , 奥能 登人の 28.25 ，能登南部人の 20.92 を筆頭とし て他の地方人とは T.D. が大きく近親度がみ とめられない。

\section{6. 頭長耳頭高指数}

頭長耳頭指数に頭長に対する頭高の 比を示 す指数值で，周防人の成績は $70.40 \pm 0.26$ であ る。大和人の 71.06 ，播磨人の 71.25 より小で あるが，出雲人の 69.20 をはじめとして巨摩 人の 69.11 , 備中人の 67.31 , 因幡人の 64.55 な ぞ各地方人こ非常に大きな差を示している。 これを頭最大長，耳頭高及び頭長耳頭高指数 の関係図にて考察するに，この指数値の差は 頭最大長より，耳頭高の差による影響が強く 作用していることがわかる。

Saller の頭長耳頭高指数頭型分類によると， 第 11 表の様に高頭型に $84.18 \%$ ぞくし，中頭 型に $10.35 \%$ ，低頭型に $5.47 \%$ ぞくしている. これは地理的に近い位置にある出雲人，備中 人の分類曲線と近似している．又巨摩人，信 州安罢人とも同様な分布状態を示しているが， 越中人，庄内人，磐城人とは異つた分類曲線 を示している．乙かしこつに特箻すべきこと は，地理的に中国山脈を越せばすぐ行けるこな りの因幡人とのこの分類曲線の差異で岕る。こ れもすべて他地方人との頭最大長の差より耳 
第 11 表 頭長耳頭高指数分類表

\begin{tabular}{|c|c|c|c|c|}
\hline 頭 & 型 & 低 頭 型 & 中 頭 型 & 高 頭 型 \\
\hline \multicolumn{2}{|c|}{ 聑長耳頭高指数 } & $\sim 57.9$ & $58.0 \sim 62.9$ & $63.0 \sim$ \\
\hline 周 & 防 & $5.47 \%$ & $10.35 \%$ & $84.18 \%$ \\
\hline 因 & 幡 & 9.88 & 16.21 & 73.91 \\
\hline 備 & 中 & 2.58 & 11.15 & 86.27 \\
\hline 播 & 磨 & 0.93 & 7.84 & 91.23 \\
\hline 高 & 麗 & 1.57 & 8.47 & 89.96 \\
\hline 千葉 中 & 部 & 0.73 & 8.99 & 90.28 \\
\hline 八 丈 & 島 & 1.54 & 8.59 & 90.51 \\
\hline 出 & 雲 & 0.86 & 11.80 & 87.33 \\
\hline 村 山盆 & 地 & 5.60 & 28.80 & 65.60 \\
\hline 高千 & 穂 & 2.79 & 19.76 & 77.45 \\
\hline 東 & 海 & 0.83 & 10.95 & 88.23 \\
\hline 巨 & 磨 & 0.71 & 12.31 & 86.98 \\
\hline 信 州 飯 & 田 & 0.00 & 9.50 & 90.50 \\
\hline 信州上伊 & 那 & 0.00 & 8.00 & 92.00 \\
\hline 岩 代 熱 & 海 & 0.52 & 12.43 & 87.05 \\
\hline 信 州 安 & 愚 & 1.32 & 14.18 & 84.50 \\
\hline 日 & 立 & 0.00 & 5.46 & 94.54 \\
\hline 太 & 和 & 0.49 & 2.21 & 97.30 \\
\hline 飛 & 弾 & 2.37 & 16.06 & 81.57 \\
\hline 三 宅 & 島 & 2.40 & 17.60 & 80.00 \\
\hline 信 州 北 & 部 & 2.82 & 19.94 & 77.24 \\
\hline 越 & 中 & 3.79 & 32.40 & 64.81 \\
\hline 磐 & 城 & 13.26 & 24.05 & 62.69 \\
\hline 庄 & 内 & 7.18 & 33.44 & 59.38 \\
\hline 埼 玉 東 & 部 & 0.40 & 12.80 & 86.80 \\
\hline
\end{tabular}

頭高の差が，この指数の差異に強く影響して いることを示すものである。

型差によつて他地方人と比較すると，大和 人の 2.66 が最も近く, 播磨人の 2.71 , 信州飯 田人の 3.46 , 巨摩人の 4.61 , 出雲人の 5.28 が 近親度がこいのみで他の 地方人とは T.D. 10.00 以上を示して近親度のうすいことを示 しているが，これも耳頭高の差がこのような 差を示めさせたのであろう. 女子の指数值は 68.21 で山る。

7. 頭巾耳頭高指数

頭巾耳頭高指数は耳頭高の頭最大巾に対す る比で岕る、周防人は $85.25 \pm 0.32$ であり，大
第 12 表 頭長耳頭高指数に於ける 周防地方人と他地方人との型差

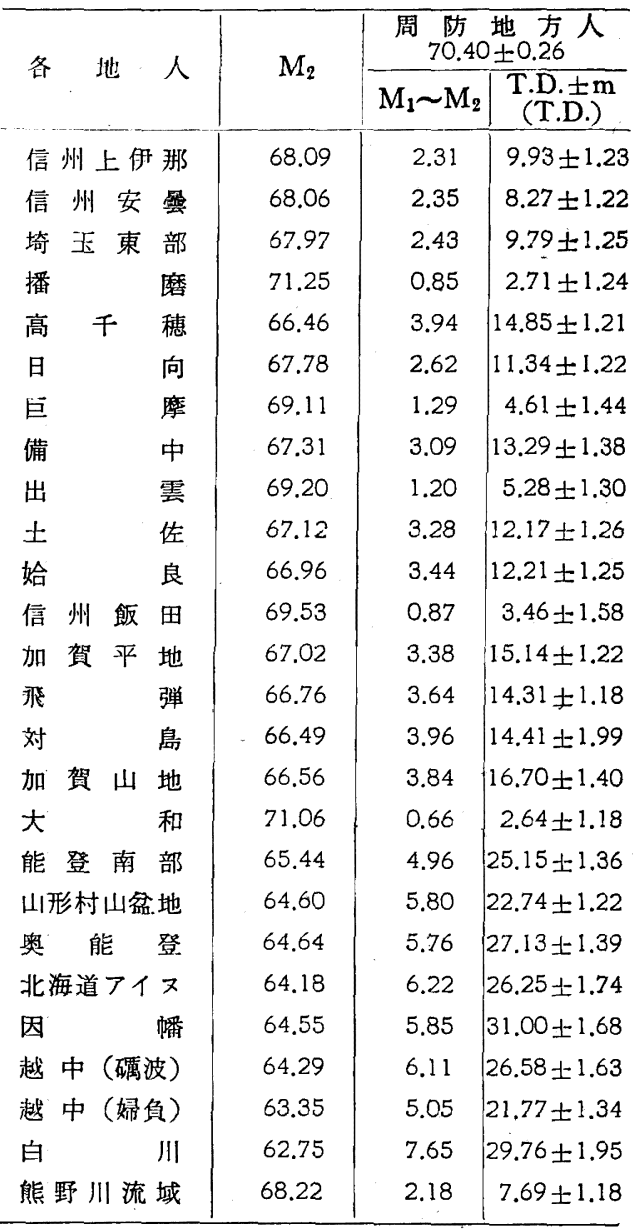

和人の 85.05 , 日向人の 84.64 , 加賀平地人の 84.48 ，播磨人の 86.05 で山るが，出雲人の 83.55 ，備中人の 81.55 乙は有意の差が認めら れる. 又近接の因幡人の 78.32 とは 7.93 と云 う大差があるのは特異な事実である。型差に 扣いても因幡人とは 25.37 ，白川人と 22.69 と 大差が認められるが，大和人との 0.64 , 日向 人の 1.99 , 播磨, 信州安曇, 加賀平地, 土佐 人など 型差 5.00 以下で近親度がつよい。 又 Martin, Saller の頭巾耳頭高指数による頭型 分類を示したものが第13表のように，巨 大型に $47.6 \%$ で最も多く，次に Tapeino. 
第 13 表 頭巾耳頭高指数分類表

\begin{tabular}{|c|c|c|c|c|}
\hline 頭 & 型 & $\begin{array}{r}\text { Tapeino } \\
\text { Kephal }\end{array}$ & $\begin{array}{r}\text { Meterio } \\
\text { Kephal }\end{array}$ & $\begin{array}{l}\text { Akro } \\
\text { Kephal }\end{array}$ \\
\hline 頭巾耳頭高 & 指数 & $\sim 78.9$ & $79.0 \sim 84.9$ & $85.0 \sim$ \\
\hline 周 & 防 & $27.01 \%$ & $25.83 \%$ & $47.16 \%$ \\
\hline 因 & 幡 & 45.06 & 39.13 & 15.81 \\
\hline 備 & 中 & 26.33 & 44.43 & 29.24 \\
\hline 播 & 磨 & 13.99 & 31.53 & 54.48 \\
\hline 高 & 鹿 & 20.47 & 39.37 & . 40.16 \\
\hline 出 & 雲 & 17.29 & 44.71 & 38.00 \\
\hline 巨 & 摩 & 14.63 & 49.01 & 36.36 \\
\hline 大 & 和 & 13.74 & 40.47 & 45.79 \\
\hline 信 州 安 & 量 & 27.60 & 37.43 & 34.97 \\
\hline 信 州 飯 & 田 & 23.00 & 44.00 & 33.00 \\
\hline 飛 & 弾 & 24.91 & 42.22 & 32.88 \\
\hline 八 丈 & 島 & 24.10 & 42.80 & 33.08 \\
\hline 三 宅 & 島 & 30.40 & 39.20 & 30.40 \\
\hline 高千 & 穗 & 36.80 & 46.00 & 17.20 \\
\hline 村山盆 & 地 & 40.48 & 44.48 & 15.04 \\
\hline 日 & 立 & 4.33 & 48.00 & 40.67 \\
\hline 千葉 中 & 部 & 24.04 & 43.12 & 32.84 \\
\hline 磐 & 城 & 33.71 & 34.09 & 32.20 \\
\hline 越 & 中 & 23.34 & 47.48 & 30.16 \\
\hline 信州上伊 & 那 & 18.00 & 53.00 & 29.00 \\
\hline 岩 代 熱 & 海 & 7.13 & 55.60 & 27.27 \\
\hline 信 州 北 & 部 & 29.90 & 44.35 & 25.75 \\
\hline 庄 & 内 & 54.81 & 33.93 & 11.26 \\
\hline 埼 玉 東 & 部 & 19.60 & 45.60 & 34.80 \\
\hline
\end{tabular}

Kephal の 27.01\% 中顽型の $25.83 \%$ となつて いる. その分類曲線を比較してみたが他地方 人と少し異つた曲線を示している。 巨大型の $47.16 \%$ によりこの指数値 85.25 が古屋一門の 計測値の中では大なる 部に入る 原因となつて いるのであろう．女子の 指数值は 83.18 であ る。

\section{8. 最小前頭巾}

最小前頭巾は，前額両側の Linea Temporalis の後方凹部にて最短巾を計測した。周防 人の測定値は $125.66 \pm 0.28$ と云; 非常に大き な值が出て招り，全ての地方人と有意の差が 岕る。

すなわち大和人の 112.91 , 出雲人の 111.62 ,
第 14 表 頭幅耳頭高指数に於ける周防地方人 と他地方人の型差

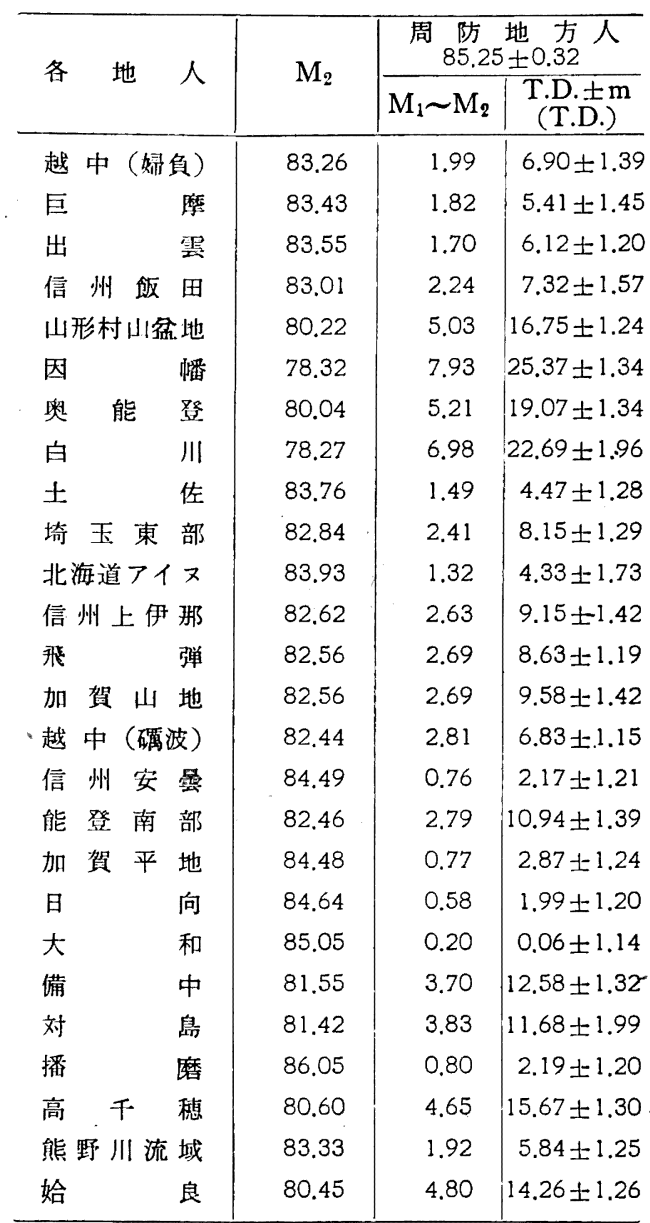

播磨人の 114.86 , 備中人の 106.41 , 北海道了 イヌの $108.5 \mathrm{~mm}$ などの差である。この為に 頭巾前頭巾指数も大和, 出雲, 播磨, 備中人 の 73.70，73.41，74.87，70.30 よりはるかに大 きな 82.66 を示すようになつたので嵓る。

\section{VI 顔面に関する研究成績}

顔面に関する測定は軀幹，四肢及び頭部に 於ける諸計測並びに 指数と共に人種比較上極 めて重要な指標をなしている。いわゆる “顔 つき”を数字で示すわけで，これらの計測值 指数値を一括して第 15 表に示す. 
第 15 表 顔面の計測值及び指数值 (周防地方人 $\mathrm{N}=565$ )

\begin{tabular}{|c|c|c|c|}
\hline 形 & $\mathrm{M} \pm \mathrm{m}$ & $\sigma$ & V \\
\hline 顴 骨 弓幅 (mm) & $136.90 \pm 0.32$ & 5.46 & 3.98 \\
\hline 顶幅顧留 弓幅指数 & $90.24 \pm 0.17$ & 4.04 & 4.48 \\
\hline 顧骨弓幅前頭幅指数 & $91.78 \pm 0.23$ & 5.44 & 5.92 \\
\hline 下靧角幅 (mm) & $112.48 \pm 0.32$ & 7.58 & 6.73 \\
\hline 顧骨湢下顎角巾指数 & $82.20 \pm 0.23$ & 5.42 & 6.59 \\
\hline 形態顔面高 (mm) & $119.45 \pm 0.25$ & 5.85 & 4.89 \\
\hline 形態顔面 指数 & $87.38 \pm 0.24$ & 5.68 & 0.50 \\
\hline
\end{tabular}

\section{1. 顴骨弓巾}

顴骨弓巾は頭巾， 下顎角巾と共に顔面部の 横経を示す三つの重要な計測値として Kretchmer, Sigaud, Kruse の体型分類に附随して 顔型分類上重視されている。即ち計测值及び これらの指数を求めて比較するならば一層よ い価值を示すものである.又, 顧骨弓巾は環境 及び外的因子の影響を被ることも僅少であり， 遺伝的関係もよく示し变異係数も僅少で岕る と云われている．先人の計測值による変異係 数はいずれも 3.00〜4.00である.

周防人の計測値の平均值は $136.90 \pm 0.23$ で, 大和人の 142.13 , 出雲人の 142.17 , 播磨人の 142.98 , 備中人の 141.05 , 因幡人の $140.12 \mathrm{~mm}$ に比して相当大きな差を示している．古屋一 門の計測地では, 硫球人の $137.12 \mathrm{~mm}$, 土佐人 の $139.70 \mathrm{~mm}$ ，がこれに近い值を示している のみで，最も小さい值を示している.

\section{2. 頭巾顴骨弓巾指数}

顧骨弓巾の頭最大巾に対する比であり，前 述したように顔型を示す重要な指数の一つで ある、周防人の平均值は 90.24 である、大和 人の 92.88 , 出雲人の 93.10 , 備中人の 93.60 , 播磿人の 92.97 , 巨摩人の 93.21 , 北海道アイ ヌの 95.36 より小さ，有意の差を示してい るが，因幡人の 89.74 より大きい，乙かし因 幡人とは有意の差をみとめられない。

3. 顴骨弓巾前頭巾指数

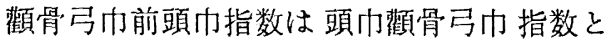

共に顔型を示す重要な指数値である。

周防人の $91.78 \pm 0.23$ は他地方人と非常に異 つた值を示しているが，これる全て最小前頭 巾の值が他地方人と異つた大きな 数值を示し ていることが強く影響しているので岗る．女 子の計湖値は 93.52 で出る。

\section{4. 下顎角巾}

下顎角巾は，顔面下部の横径を示す毛ので， 顧骨引币と共に顔型分類上重要視されている。 又 Sigaud は下顎角巾の大小に依り, 消化器 型，脳型などの体型分類判定に利用している。 测定 成績は $112.48 \pm 0.32$ で大和人の 112.70 , 播磨人の 112.96 より小さく, 出雲人の 109.70 , 備中人の 109.75 , 巨摩人の 109.30 , 高千穂人 の $111.68 \mathrm{~mm}$ より大である。

5. 顴骨·弓巾下顎角巾指数

この指数は顔型の中部と下部との比であり， 最もよく顔型分類に使用されている。．顔面下 半分の狭型, 広型が示されるので顔型研究上 かくことの出来ない指数とされている．周防 人の指数値は $82.20 \pm 0.23$ で相当大きく, Saller. Lundburg の顔型分類表による広型にぞ くしている。これは顎骨弓巾に対して下顎角 ウの比が大きいことを示している．第16表の ように広型と過広型に $73 \%$ ぞくしているこ そでもわかる。この分類曲線は他地方人とは 全然異り，わずかに因幡人といさ〉か近似し ているのみである。これもこの周防人の一つ の特異なあらわれであろう。大和人の 79.32 ， 出雲 人の 77.11 , 播磨 人の 79.39 , 備中人の 77.36 , 甲斐人の 77.34 , 北海道アイヌ人の 77.85 ， 越中人の 77.76 , 三宅島人の 77.60 ，八丈島人

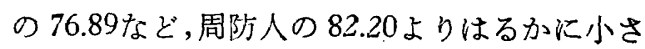
い. 因幡人のみ 83.16 で因憣人の下顎 角巾 $118.16 \mathrm{~mm}$ が非常に強く作用しているのであ るが，周防人の場合は，下顎角巾の $112,48 \mathrm{~mm}$ よりむしろ顧骨局内の $136.90 \mathrm{~mm}$ という小さ さが影響しているので岕うっ。 
第 16 表 顴骨弓巾下顎角巾指数顔型分類表

\begin{tabular}{|c|c|c|c|c|c|c|}
\hline 顏 & 型 & 過㹨型 & 狭型 & 中等型 & 広 型 & 過広型 \\
\hline \multicolumn{2}{|c|}{$\begin{array}{l}\text { 顴骨弓巾下 } \\
\text { 䫇角巾指数 }\end{array}$} & 69.9 & $i_{74.9}^{70.0}$ & $i_{79.9}^{75.0}$ & $i_{84.9}^{80.0}$ & $i^{85.0}$ \\
\hline 周 & 防 & $\begin{array}{r}\% \\
2.65\end{array}$ & $\begin{array}{r}\% \\
7.61\end{array}$ & $\begin{array}{r}\% \\
16.64\end{array}$ & $\begin{array}{r}\% \\
32.74\end{array}$ & $\begin{array}{r}\% \\
40.36\end{array}$ \\
\hline 播 & 磨 & 0.93 & 10.80 & 48.42 & 32.03 & 7.82 \\
\hline 高 & 毙 & 0.59 & 21.65 & 51.18 & 21.66 & 4.92 \\
\hline 信州上自 & 那 & 1.00 & 20.00 & 52.00 & 26.00 & 11.00 \\
\hline 八 丈 & 島 & 2.57 & 27.18 & 51.02 & 18.46 & 0.77 \\
\hline 大 & 和 & 0.40 & 7.67 & .52 .21 & 36.12 & 3.87 \\
\hline 飛 & 弾 & 1.49 & 26.03 & 51.18 & 20.42 & 0.87 \\
\hline 䚀 & 城 & 1.14 & 14.21 & 52.27 & 26.51 & 5.81 \\
\hline 越後東莎 & 原 & 0.57 & 16.47 & 52.31 & 29.68 & 0.97 \\
\hline 三 宅 & 島 & 1.60 & 20.00 & 52.80 & 24.80 & 0.80 \\
\hline 日 & 立 & 0.33 & 18.00 & 54.00 & 25.67 & 2.00 \\
\hline 庄 & 内 & 0.33 & 10.77 & 52.86 & 33.28 & 2.77 \\
\hline 信 州 北 & 部 & 0.84 & 12.29 & 52.83 & 31.71 & 2.33 \\
\hline 伊 & 那 & 0.94 & 18.16 & 53.74 & 25.66 & 1.50 \\
\hline 巨 & 摩 & 2.37 & 23.32 & 54.54 & 17.00 & 2.77 \\
\hline 越 & 中 & 1.07 & 18.27 & 56.45 & 23.65 & 0.53 \\
\hline 信 州 飯 & 田 & 0.50 & 15.00 & 57.50 & 25.00 & 2.00 \\
\hline 信 州 安 & 叠 & $0.38^{!}$ & 5.48 & 58.60 & 34.41 & 1.13 \\
\hline 岩 代 熱 & 海 & 0.71 & 10.14 & 59.61 & 27.09 & 2.45 \\
\hline 相 棪 平 & 野 & 1.00 & 19.75 & 54.75 & 21.00 & 3.50 \\
\hline 千葉中 & 部 & 0.18 & 8.99 & 55.78 & 32.11 & 2.94 \\
\hline 出 & 雲 & 0.60 & 22.72 & 60.72 & 15.01 & 0.94 \\
\hline 埼 玉 東 & 部 & 1.80 & 21.80 & 50.20 & 24.60 & 1.60 \\
\hline 因 ， & 幡 & 0.00 & 0.99 & 14.03 & 42.49 & 42.49 \\
\hline 僙 & 中 & 1.45 & 19.06 & 54.94 & 21.97 & 2.58 \\
\hline
\end{tabular}

\section{5. 形態顔面高}

形態顔面高は，顔面の縦径を示す数值であ る.その測定には二方法市るが，私は Martin の法により，鼻根正中点 (Nasion) と, 下顎 下緑正中点（Gnation）との投射高の方法に依 り測定した．計測値は $119.45 \pm 0.25$ で播磨人 の $122.28 \mathrm{~mm}$, 大和人の $121.40 \mathrm{~mm}$, 出雲人の $122.80 \mathrm{~mm}$, 備中人の $120.68 \mathrm{~mm}$, 北海道アイ 又の $121.30 \mathrm{~mm}$ 上り小さく, 飛弾人の 119.30 $\mathrm{mm}$, 奥能登人の $119.70 \mathrm{~mm}$ と近似值を示して いる.女子の計測値は $112.45 \mathrm{~mm}$ こ小さい。

\section{6. 形態顔面指数}

形態顔面指数は 形態顔面高と顴骨弓巾との
比であり，顔面の横径と縦径との関係をあら わし, 顔型分類上重要なものである.

周防人の平均値は 87.38 で中等型に入る. 大和, 出雲, 倩中, 播磨人の $85.26 \sim 86.42$ な どより大きく，加贺山地人の 87.44 ，加贺平地 人の 87.70 , 対馬人の 87.62 と近似している. 因播人の 88.78 より小である. 形態顔面指数 による顔型分類表は第 17 表の様になるが，中 等型に $45.38 \%$ と最高で出り，次に狭型の $30.19 \%$ があり，広型の $13.27 \%$, 過狭型の 7.12 $\%$ ，過広型の $4.04 \%$ とつづいている.この分 布状態は出雲人, 岩代熱海人, 八丈島人, 日 立人と類似している．型差では，加賀山地人

第 17 表 形態顔面指数顔型分類表

\begin{tabular}{|c|c|c|c|c|c|c|}
\hline 顔 & 型 & 過広型 & 広 型 & 中等型 & 狭 型 & 過狭型 \\
\hline 形態顔面指 & 旨数 & $\sim 78.9$ & $\begin{array}{r}79.0 \\
83.9 \\
83.9\end{array}$ & $\mid \begin{array}{r}84.0 \\
87.9\end{array}$ & $\left|\begin{array}{rr}88.0 & \\
& 9 \\
& 92.9\end{array}\right|$ & $93.0 \sim$ \\
\hline 周 & 防 & $\begin{array}{r}\% \\
4.04\end{array}$ & $\begin{array}{r}\% \\
13.27\end{array}$ & $\begin{array}{r}\% \\
45.38 \\
\end{array}$ & $\begin{array}{r}\% \\
30.19\end{array}$ & $\begin{array}{r}\% \\
7.12\end{array}$ \\
\hline 播 & 磨 & 8.58 & 27.05 & 28.17 & 29.11 & 7.09 \\
\hline 高 & 籍 & 2.95 & 18.50 & 28.94 & 36.42 & 13.19 \\
\hline 庄 & 内 & 0.82 & 13.21 & 28.87 & 39.48 & 17.62 \\
\hline 磐 & 城 & 4.36 & 23.48 & 28.60 & 30.87 & 12.69 \\
\hline 文 & 島 & 1.28 & 22.56 & 36.67 & 29.23 & 10.23 \\
\hline 出 & 雲 & 4.36 & 26.01 & 33.58 & 28.21 & 7.84 \\
\hline 巨 & 摩 & 3.56 & 23.72 & 35.57 & 28.46 & 8.69 \\
\hline 三 宅 & 島 & 6.40 & 26.40 & 30.40 & 30.40 & 6.40 \\
\hline 越後東浦 & 有原 & 9.00 & 21.11 & 27.69 & 31.37 & 10.82 \\
\hline 岩 代 熱 & 海 & 1.75 & 15.03 & 49.29 & 32.89 & 1.07 \\
\hline 日 & 向 & 1.00 & 14.17 & 48.17 & 36.49 & 0.17 \\
\hline 相 模 平 & 野 & 1.00 & 9.75 & 26.75 & 39.00 & 23.50 \\
\hline 信州上伊 & 阝 那 & 8.10 & 33.80 & 29.60 & 24.00 & 4.50 \\
\hline 越 & 中 & 8.06 & 29.03 & 31.72 & 24.19 & 6.98 \\
\hline 大 & 和 & 9.60 & 32.73 & 29.21 & 21.96 & 6.49 \\
\hline 千 葉 中 & 部 & 6.24 & 28.44 & 33.21 & 23.85 & 8.26 \\
\hline 飛 & 弾 & 17.81 & 35.24 & 29.64 & 14.82 & 2.49 \\
\hline 信 州 飯 & 田 & 10.00 & 29.00 & $35: 50$ & 22.00 & 5.50 \\
\hline 信 州 安 & 雲 & 12.85 & 40.08 & 28.17 & 15.31 & 3.59 \\
\hline 伊 & 那 & 8.80 & 32.02 & 31.09 & 23.22 & 4.87 \\
\hline 埼 玉 東 & 部 & 11.20 & 31.40 & 32.80 & 18.40 & 6.20 \\
\hline 因 & 䠦 & 0.59 & 9.49 & 25.89 & 36.56 & 27.47 \\
\hline 犕 & 中 & 8.72 & 23.59 & -29.24 & 31,34 & 7.11 \\
\hline
\end{tabular}


第 18 表 形態顔面指数における周防地方人 と他地方人との型差

\begin{tabular}{|c|c|c|c|}
\hline \multirow{2}{*}{ 各 } & \multirow{2}{*}{$\mathrm{M}_{2}$} & \multicolumn{2}{|c|}{$\begin{array}{c}\text { 周防地一方人 } \\
87.38 \pm 0.24\end{array}$} \\
\hline & & $\mathrm{M}_{1} \sim \mathrm{M}_{2}$ & $\begin{array}{l}\text { T.D. } \pm \mathrm{m} \\
\text { (T.D.) }\end{array}$ \\
\hline 大 & 85.26 & 2.12 & $8.06 \pm 1.04$ \\
\hline 出 & 86.42 & 0.96 & $3.65 \pm 1.00$ \\
\hline 巨 & 86.93 & 0.45 & $1.72 \pm 0.14$ \\
\hline 信 州 安 壪 & 84.07 & 3.31 & $13.34 \pm 1.23$ \\
\hline 信州上伊那 & 85.22 & 2.16 & $8.64 \pm 1.34$ \\
\hline 信 州 飯 田 & 85.24 & 2.14 & $8.17 \pm 1.56$ \\
\hline 備 中 & 85.72 & 1.66 & $6.31 \pm 1.18$ \\
\hline 熊野川流域 & 83.88 & 3.50 & $13.27 \pm 1.18$ \\
\hline 埼 玉 東 部 & 84.88 & 2.50 & $11.70 \pm 1.24$ \\
\hline 播 & 86.18 & 1.20 & $4.42 \pm 1.22$ \\
\hline 姶 & 86.54 & 0.84 & $3.78 \pm 1.26$ \\
\hline 高 千 & 83.24 & 4.14 & $15.03 \pm 1.22$ \\
\hline 因 & 88.78 & 1.40 & $4.90 \pm 1.21$ \\
\hline 対 & 87.62 & 0.24 & $0.90 \pm 2.05$ \\
\hline 日 & 84.95 & 2.43 & $10.18 \pm 1.12$ \\
\hline 土 & 86.43 & 0.95 & $3.87 \pm 1.35$ \\
\hline 飛 & 83.51 & 3.87 & $15.05 \pm 1.14$ \\
\hline 加賀平地 & 87.70 & 0.32 & $1.27 \pm 1.03$ \\
\hline 加 賀 山地 & 87.44 & 0.06 & $0.25 \pm 1.37$ \\
\hline 山形村山盆地 & 83.36 & 4.02 & $14.90 \pm 1.16$ \\
\hline 白 川 & 84.03 & 3.35 & $13.37 \pm 1.99$ \\
\hline 奥 能 登 & 84.30 & 3.08 & $12.26 \pm 1.22$ \\
\hline 越中（㷌負） & 86.91 & 0.47 & $1.91 \pm 1.32$ \\
\hline 能 登南 部 & 83.62 & 3.76 & $15.57 \pm 1.09$ \\
\hline 越 中（礍波） & 85.55 & 1.83 & $7.47 \pm 1.70$ \\
\hline 北海道アイヌ & 85.32 & 2.06 & $7.97 \pm 1.74$ \\
\hline
\end{tabular}

の T.D. 0.25 が最も近く, 対島, 加賀平地, 巨摩, 越中婦負人と T.D. 2.00 以下で近親度 が大である。しかし, 飛弾, 白川, 能登南部 人は T.D. 15.00 以下で近親度はうすい.女 子の指数值は 88.33 と大きい.

\section{VII 平均型差による綜合比較}

以上個々の計測値及び 指数值について比較 検討を行つて来たが，全部を綜合比較し，総 括的に互いに類縁度の有無を知る必要がある。

人種的親疎の度合を示すには色々の方法が めるが，現在最む広く用いられている方法は
種族型差である、型差は Mollison により係 数を 50 として考案された. その後 Poniatoueskyにより便宜上係数を 100 に修正された。

古屋は更に係数を 10 とし, 計測法の項で示 した T.D. の方式に修正した。平均型差も変 異係数に関係なく単純に平均して平均型差を 算出するのは不合理である為，1/V をかける ことにより変異係数によつて重みづけた上で 平均した。この修正した型差及び平均型差の 算出方法により各地方人と比較して次の様な 成績を得た。

又, 図に示したものが第 3 図である.

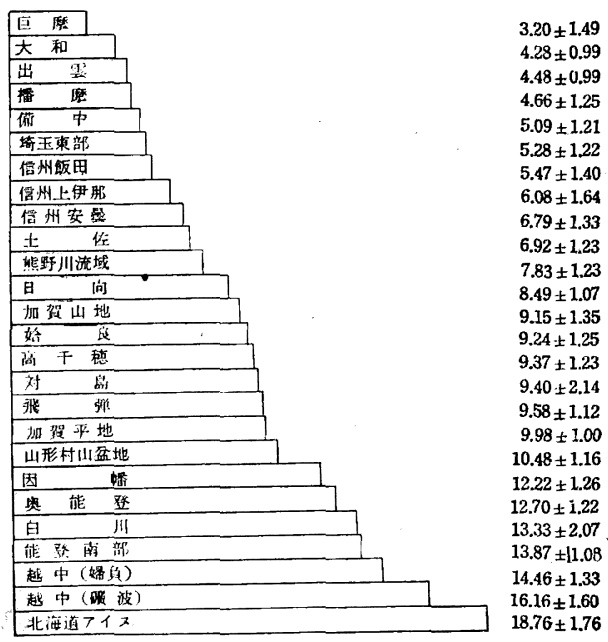

第 3 図周防人対各地方人の平均型差図

平均型差については身長，頭最大長，頭最 大巾, 頭長巾指数, 耳頭高, 頭長耳頭高指数, 頭巾耳頭高指数，形態顔面指数の 代表的 8 項 目について算出した。そ結果巨摩人の 3.20 を筆頭に大和人の 4.28 , 出雲人の 4.48 , 播磨 人の 4.66 , 備中人の 5.09 と地域的に近接して いる地方人及び 歷史的に 関係があるとされて いる地方人に近親度が濃厚である。又埼玉東 部人，信州飯田人が M.T.D. 500 台となつて いる。これらは全て，大陸系より移住した歷 史がのこされている地方が多いことも興味あ る事実である。 
第 19 表 周防地方々他地方人との 各項目別近親度表

\begin{tabular}{|c|c|c|}
\hline & 型差 4.00 以下 & 型差 15.00 以上 \\
\hline 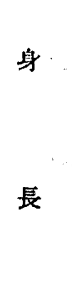 & $\begin{array}{l}\text { 巨摩, 埼玉東部, 土 } \\
\text { 佐, 村山盆地, 北海 } \\
\text { 道アイヌ, 備中, 出 } \\
\text { 雲, 高千穂, 奥能登 } \\
\text { 白川, 能登南部, 熊 } \\
\text { 野川流域, 日向, 加 } \\
\text { 賀山地, 加賀平地, }\end{array}$ & v \\
\hline $\begin{array}{l}\text { 頭 } \\
\text { 最 } \\
\text { 大 } \\
\text { 長 }\end{array}$ & $\begin{array}{l}\text { 大和, 出墨 巨摩 信 } \\
\text { 州饭田 }\end{array}$ & $\begin{array}{l}\text { 土佐, 熊野川流域, } \\
\text { 日向, 対島, 北海道 } \\
\text { アイヌ, 越中䃻波, } \\
\text { 越中婦負, 飛弾, 能 } \\
\text { 登南部 }\end{array}$ \\
\hline $\begin{array}{l}\text { 頭 } \\
\text { 最 } \\
\text { 大 } \\
\text { 巾 }\end{array}$ & 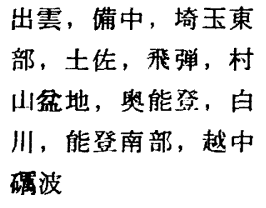 & \\
\hline $\begin{array}{l}\text { 頭 } \\
\text { 長 } \\
\text { 巾 } \\
\text { 指 } \\
\text { 数 }\end{array}$ & $\begin{array}{l}\text { 高千穗, 大和, 備中 } \\
\text { 出雲, 巨摩, 埼玉東 } \\
\text { 部, 信州上伊那, 因 } \\
\text { 幡, 姶良, 播栖, 能 } \\
\text { 野川流域, 加賀山地 }\end{array}$ & $\begin{array}{l}\text { 北海道アイヌ, 加賀 } \\
\text { 平地, 能登南部, 越 } \\
\text { 中礌波, 越中婦角 }\end{array}$ \\
\hline $\begin{array}{l}\text { 頭 } \\
\text { 高 }\end{array}$ & 大和 & $\begin{array}{l}\text { 備中, 村山搵地, 白 } \\
\text { 川, 奥能登, 能登俑 } \\
\text { 部, 越中属波, 因幡 } \\
\text { 加賀山地 }\end{array}$ \\
\hline $\begin{array}{l}\text { 頭指 } \\
\text { 長 } \\
\text { 耳 } \\
\text { 頭 } \\
\text { 高数。 }\end{array}$ & $\begin{array}{l}\text { 大和, 播穈, 信州飯 } \\
\text { 田 }\end{array}$ & $\begin{array}{l}\text { 因幡, 村山盆地, 奥 } \\
\text { 能登, 能登南越, 部 } \\
\text { 中䂗波, 越中婦負, } \\
\text { 加賀平地, 加賀山地 } \\
\text { 白川 }\end{array}$ \\
\hline $\begin{array}{l}\text { 䪶指 } \\
\text { 品 } \\
\text { 頭 } \\
\text { 高数 }\end{array}$ & $\begin{array}{l}\text { 大和, 播磨, 信州安 } \\
\text { 雲, 日向, 加賀平地 }\end{array}$ & $\begin{array}{l}\text { 村山盆地, 白川, 奥 } \\
\text { 能登, 因幡, 高千穂 }\end{array}$ \\
\hline $\begin{array}{l}\text { 形指 } \\
\text { 態 } \\
\text { 䌿 } \\
\text { 高数 }\end{array}$ & $\begin{array}{l}\text { 出雲, 巨摩, 土佐, } \\
\text { 越中婦負, 加賀山地 } \\
\text { 姶良, 対息, 加賀平 } \\
\text { 地 }\end{array}$ & $\begin{array}{l}\text { 高千穂, 飛弾, 能登 } \\
\text { 南部 }\end{array}$ \\
\hline
\end{tabular}

第 20 表 周防地方人と他地方との 各項目別近親度の度数表

\begin{tabular}{|c|c|}
\hline 型差 4.00 以下 & 型差 15.00 以上 \\
\hline 大和(5) 䚚中(3) 出雲 & 備中(1)，北海道アイヌ \\
\hline (5) 信州安曇(1) “巨摩 & (3) 越中磸波 (4) 越中 \\
\hline (4) 信州上伊那(1) 信 & 婦負(3）＼cjkstart加賀平地(2) \\
\hline 州饭田(2) 因幡(1) 埼 & 加賀山地(2) 対島(1) \\
\hline 玉東部(3) 対島(1) 熊 & 村川永地(3) 白川(3) \\
\hline 野川流城(2) 北海道了 & 奥能登(3) 能登南部(5) \\
\hline イヌ(1) 土佐(3) 越中 & 飛弾(2) 土佐(1) 信州 \\
\hline 磼波(1)＼cjkstart越中婦負(1) & 上伊那(1) 因幡(3) 熊 \\
\hline 高千穂(2) 姶良(2) 播 & 野川流域(1) 日向(1) \\
\hline 磨(3) 日向(3) 飛弾(1) & 高千穂(2) \\
\hline 加賀山地(3) 加賀平地 & \\
\hline (3) 村山盆地(2) 奥能 & \\
\hline 登(2) 白川(2) 能登南 & \\
\hline 部(2) & \\
\hline
\end{tabular}

これに反し, 北海道アイヌ人の 18.76 と共 に日本内地に打いてアイヌ系と目されている 越中人 $(16.16,14.46)$ や能登南部人, 奥能登 人などは M.T.D. 12.00 以上を示し, 近親度 がうすくなつているのも面白い事実である。

これは周防人が, 播磨人, 備中人などと同樣に 一連の特色を示するので山るといえる。

項目別の近親度をるとめたものが第 19 表及 び第 20 表である.T.D. 4.00 以下を示した度 数は, 大和人, 出雲人の 5 項目を筆頭に巨摩 人の 4 項目, 備中人, 播磨人, 土佐人, 日向 人, 埼玉東部人の 3 項目であるが，こつで注 目すべき事は加賀山地人と加賀平地人の 3 項 目のあることである. 逆に T.D. 15.00 以上を 示し近親度がうすいるのには, 能登南部人の 5 項目を筆頭に越中磈波の 4 項目, 北海道了 イヌ, 越中婦負, 白川, 奥能登, 村山盈地人 の 3 項目である.こっでも地理的に非常に近 接している因幡人と 3 項目のT.D. 15.00以上の るのがあることは考えねばならぬことである。 こっに招いても，平均型差による考察と同椂 な結果をあらわしていることがわかる。 


\section{VII 偏差折線による比較}

平均型差による比較法は多数の種族との近 親度を一数值で一回瞭然に 比較しうる特徵が ある. が，個々の型差の正負の方向は無視さ れている、故にこの欠点を補う為に Mollison の偏差折線図示法によつて検討してみた。こ れは偏差曲線法 $\frac{\mathrm{M}_{1}-\mathrm{M}_{2}}{\sigma_{1}}$, 偏差比曲線法 $\frac{\mathrm{M}_{1}-\mathrm{M}_{2}}{\mathrm{~m}_{1}}$, 型差曲線法 $10\left(\mathrm{M}_{1} \sim \mathrm{M}_{2}\right)\left(\frac{1}{\sigma_{1}}+\right.$ $\left.\frac{1}{\sigma_{2}}\right)$ の 3 種の方法が山るが, そのうち型差曲 線法は基線種族と被比較種族とが互に変更し ても絶対值は変らず正負が逆となるだけで基 線に対して対称的な線を画くため応用も広い。 これを用いて大和, 出雲, 越中, 北海道アイ 又人の各地方人と比較すれば第 4 図となり，そ

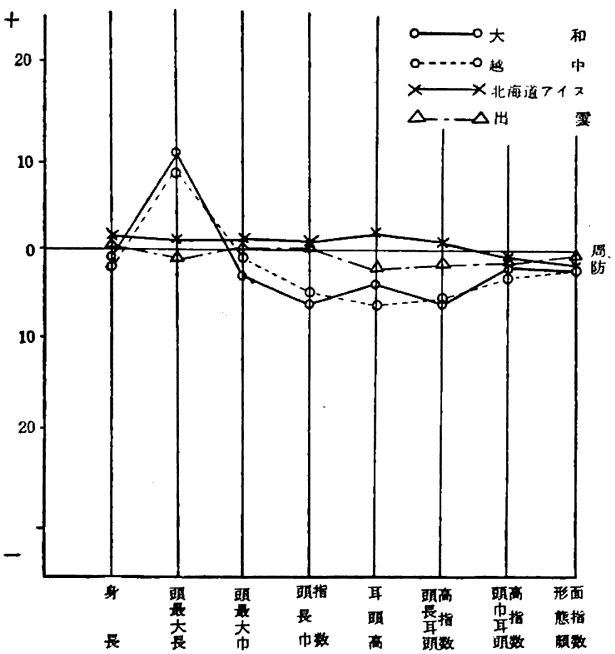

第 4 図周防地方人対各地方人型差曲線図

の正負が明瞭に示されている.周防人と大和人 及び出雲人は M.T.D. 4.28 と 4.48 と共に近親 度が浱厚であるが，大和人は周防人に対して 正のものが多く，出雲人その逆に負のものが 多いことがわかる. 又周防人は他の 3 地方人 に対し，大体に於て正のものが多い。

\section{IX 指数関係図示法による比較}

人種の近親度を知るのに各個々の計測も大
切であるが，それによつて算出される指数值は より重要であることは前にる述べた。しかし その指数值のみでは構成分子がはつきりしな い，構成分子が異つても指数值は同一である こともあり得る。故に指数值と同時に構成分 子も表わす図示法により比較検討してみた。

頭長巾指数, 頭最大長, 頭最大巾の相互関 係を図示すると第 5 図となる。

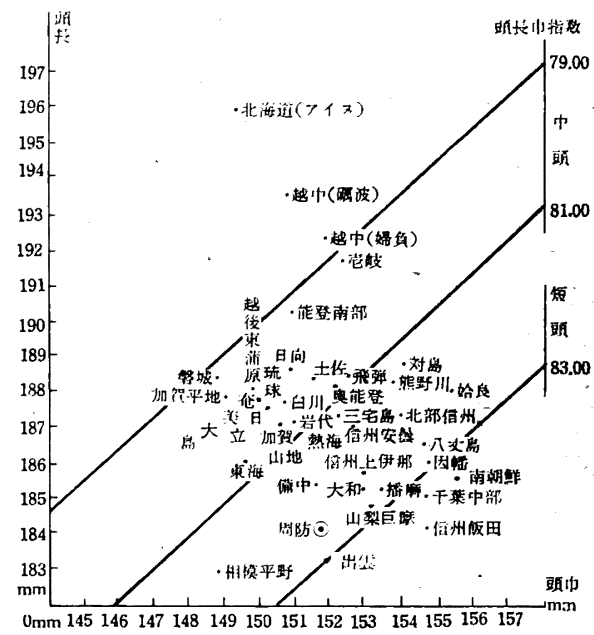

第 5 図 頭長, 頭巾, 頭長巾指数の関係図

こ〉でも大和, 巨摩，備中，出雲人と一団 となつている. しかし周防人の頭最大巾が小 さい方なので，この関係図では下方に位置し ている。 又北海道アイヌ, 越中, 能登南部人 とは相当の差があることが一目瞭然としてわ かる。

又他の相互関係図である形態顔面高, 顴骨 弓巾, 形態顔面指数の場合も大体上記と同椂 な結果が示されている。

\section{$\mathbf{X}$ 三角図示法による比較}

平均型差法, 偏差曲線法, 指数関係図示法 により他地方住民との比較検討を行つたが， 相互間の関係をより一層明かにするために， 三角図示法によつて更に比較してみた。

周防地方人を中心として，歴史的に関係の ある大和人と出雲人との関係図と，隣接して 


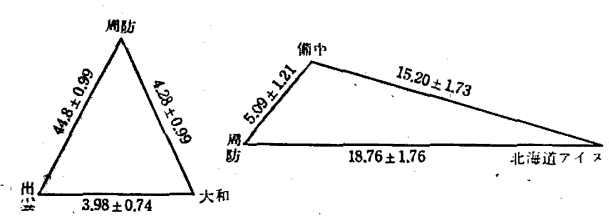

第 6 図周防地方人と他地方人との 相互三角関係図

いる備中地方人と確かに近親度が遠い乞考兄 られる北海道アイヌ人との関倸図が第 6 図で あるが，これまた一目瞭然にその近親度がわ かる. 又大和, 出雲, 周防人の三者の関係の 方が，後者の関係より密接なつながりがある ことを表している。

\section{む す び}

私は昭和 33 年 5 月より 昭和 34 年 10 月迄 1 年 5 月間, 体質人類学的見地より, 山口県周 防地方（德山の北 7 里にある 鹿野町を中心に した鹿野盈地）の地つきの住民成年男子565名 及び成年女子 325 名にういて, 軀幹四肢, 頭 部及び顔面などの生体測定を行い，27 項目の 計測値及び指数値をるとにして，詳細な考察 をして，他地方人との比較検討を行つた。そ の結果次の様な結論が出た。こつでは成年男 子のみ他地方人と比較検討した。

1）周防人の 身長の平均值は $159.98 \mathrm{~cm} て ゙$ Martin の身長分類では「小」の部にぞくして いるが，日本人男子としては「中の下」にぞ くしている.土佐人, 高千穂人, 加賀平地人, 能登南部人に近い值を示している.

2）上肢長は $71.73 \mathrm{~cm}$ で，比上肢長は 44.22 \%で Imancwski の上肢分類では，長腕が 46.05 \%で最も多く，中腕の $32.56 \%$ ，短腕の 21.39 \%をなつて括り，身長に比し上肢長が長いこ とを示している。

3) 頭最大長は $184.00 \mathrm{~mm}$ で, 信州飯田, 出雲, 巨摩人に近い。頭最大巾は $151.70 \mathrm{~mm}$ で, 土佐, 奥能登, 備中, 出雲人に近い。

4) 頭長巾指数は 82.65 で古屋一門の測定 した地区の平均値81.31をはるかにこした短
頭型にぞくしている。これは, 頭最大長が頭 最大ウに比較して小さいことを示している。 Martin の頭型分類でも短頭型に最も多く $44.15 \%$ ぞくし，中頭型の $31.86 \%$ となつてい る. 分類曲線及び型差は, 出雲, 巨摩, 播磨, 大和, 因幡, 信州上伊那人乙近親度が濃い。 北海道アイヌ，越中人とは近親度がうすい。

5）耳頭高は $129.54 \mathrm{~mm}$ で，大和，巨摩， 信州飯田, 能野川流域住民と似て括り, 日本 人の耳頭高としては大きい方である.

頭長耳頭高指数及び頭巾耳頭高指数は，そ れぞれ 70.40 と，85.25で共に大きな值を示し ているが, 共に大和, 播磨人と近親度がこい。

6）最小前頭巾は $125.66 \mathrm{~mm}$ で非常に大き な值を示して拈り，全ての地方人と有意の差 が認めら礼る. その為に顴骨弓巾前頭巾指数 が91.78で，他地方人と非常に 異つた值を示 している。

7) 顴骨弓巾は $136.90 \mathrm{~mm}$ で, 土佐, 琉球 人に近似しているが古屋一門計測地中最も小 さい值を示している。

8)，顴骨弓巾下顎角巾指数は 82.20 で相当 大きく，顔型分類で広型にぞくしている。す なわち広型と過広型に 73\%はいつている。

9）形態顔面高は $119.45 \mathrm{~mm}$ で飛弾人, 奥 能登人乞近似値を示している。形態顔面指数 は 87.38 で，中等型である. 顔型分類では出 雲人の分類䌷線乞にている。加賀, 越中, 巨 摩人と近親度が強い。

10）平均型差により，他地方人と比較うる そ, 巨摩, 大和, 出雲, 播磨, 供中, 埼玉東 部, 信州飯田人と M.T.D. 5.50 以下の值を示 しているが，大陸系より移住した歴史がのこ されている地方ばかりであることは興味深い 発見である。これに反しアイヌ系と目されて いる越中及び能登人は，北海道アイヌと共に M.T.D. 12.00 以上を示し近親度がうすい。

11）偏差折線により，共に周防人と近親度 が強い出雲人と大和人を検討したところ，大 
和人は周防人に対し正のものが多く，出雲人 は負のものが多いことがすぐわからた。

12）指数関係図示法にて周防人と他地方人 との位㯰を検討すると平均型差の場合と同様 に, 周防人は大和, 巨摩, 備中, 出雲人と一 団となりて打り，北海道アイヌ，越中人とは 相当はなれていることが判明した。

13）三角形図示法により周防，大和，出 雲，備中，北海道アイヌ人との相互関係を椧 討したが，これも平均型差の場合と同じ樣に 近親度の状態が一目暸然とわかつた。

\section{総括}

周防地方人は，体質人類学的に最も価値の 高い緒形質の測定の結果から判断すると，我 が国最高の文化をほこつていた大和人，出雲 人，備中人，巨摩人等の大陸系より移住した 民族や，大陸との交通が盛んであつた民族と 近親度が高い事が認められた。

第十代の崇神天皇の時より，大和朝廷と関 係を持ち，大和朝廷が全国統一を完成した四 世紀の半ばごろまでにその勢力下に入り，策 えてきたこの地方人は，たとえ祡を越しても 山陰侧の方が交通の便利がよいなど，山陽と山 陰の両方の影響をうけていたと考えられるが， 体質人類学的研究によりても大和人，出雲人と 殆ど同程度に種族的近親度が漕厚であり，又 地域的に隣接し，山陽道の通行の要所にある 備中人，播磨人にも近親度が大であることは 县味山る事実である。

和を終るにの犯み，終始御指学，御校浣を睗 つた恩師古屋芳雄教授及び大森暢久博士に刘し， 深く感謝を捧げます。なたろいろ御援助いた ら゙いた東大史科編算所, 篓地吅次郎氏, 及び日 医人岡部五成博士に曆く御礼电しあげます，

\section{参考 文 献}

1) Martin. R: Lehrbuch der Anthropologic Autl, (1928).

2) 古屋芳雄, 宮坂五一郎: 医学統計法 (1955)

3）清野謙次，金閣文夫：人種起源説 (1928)4

4) 松岡寿人：現代人類問題研究 (1935)

5) 人類学, 先史学講夾, 1.2.3.4.19 巻 (1940)

6) 防長風土記 (1957)

7) 都濃郡史 (1951)

8) 都濃郡自治实要 (1954)

9）料地勇次郎：周防の文化史的考察（未発表）

10）古屋芳雄： Rassenkunde der Aino (1939)

11）矢ケ崎德蔵：民族生物学研究，第 2 輯 (1936)

12）村田四郎：民族生物学研究, 第 2 輯 (1936)

13）村田四郎：民族生物学研究, 第 3 輯 (1937)

14）古屋芳雄外：民族生物学研究，第 2 輯 (1936)

15）古屋芳雄外：民族生物学研究，第 4 輯（1937）

16）加藤義治郎：民族生物学研究，第 5 輯 (1938)

17）加藤義治郎：民族生物学研究; 第 7 輯 (1939)

18) 能沢清志: 厚生科学研究 (1944)

19) 上田栄吉：十全誌 (1949)

20）大森暢久：日医大誌，17，6，(1950)

21) 高野武悦：信州医学誌， 3，1，(1954）

22）湯浅秀：日医大誌， 21，11，(1954）

23）村松稔：民族衛生，22，5，6，(1955)

24）西村義：日医大誌，22，2，(1955）

25) 山崎倫子：日医大誌, 22, 11, (1955)

26) 山崎浩：千葉医学誌, 30, 6, (1955)

27）宮坂五一郎：民族衛生，22，4，(1956）

28）荻野博：日医大誌，23，12，(1956）

29）安方魁人：日医大誌，23，4，(1956）

30) 宮坂勝蔵：日医大誌，24，7，(1957)

31）藤井章：民族街生， 25，2，(1959）

32）岡部五成：民族徆生，25，2，(1959）

33）鈴木康弘：民族衛生，25，3，(1959）

34）津村大八：民族衙生，25，4，(1959）

35）斉藤達郎：民族衙生， 25，5, (1959)

36）津村大輔：民族征生， 26，2，(1960）

37）長田宗憲：民族熦生， 26，4，(1960)

38）文部省科学研究医学関係総合研究報告書 (1948〜1953) 
A Constitutional Anthropological Study of the Inhabitants of Suhō District, Yamaguchi Prefecture, Japan

By

\section{Masahiko ASAMI}

During the period of a year and five months (May 1958-October 1659), I have from the standpoint of constitutional anthropology, made measurements of the living bodies (trunk, limbs, head, face, etc.) of 565 adult males and 325 adult females who are the inhabitants of the Suhō district of Yamaguchi Prefecture. I have made detailed observations based upon the measurement values and index values of 27 items, and have made a comparative study with those of other districts. The following is the result, although here I have restricted the comparative study to adult males.

1) The average height of the Suhō district males is $159.98 \mathrm{~cm}$ and belongs to the "small" group according to Martin's height classification, but as a Japanese adult male they belong to the "below medium" group. Their measurements resemble those of the adult males of the districts of Tosa, Takachiho, Kaga plain, and South Noto.

2) The maximum length of the head measured $184.00 \mathrm{~mm}$, resembling that of the peoples of Shinshu-Iida, Izumo, and Koma, while the maximum width of the head measured $151.70 \mathrm{~mm}$., resembling that of Tosa, Oku-Noto, Bitchu, and Izumo.

3) The index number of the length and width of the head is 82.65 , belonging to the small-head type, far exceeding the average index value of 81.31 of the district measured by Dr. Koya. This reveals the fact that the maximum length of the head is short in comparison to its maximum width. As seen in view of Martin's head classification, $44.15 \%$ of the Suhō district males belong to the small head type, and $31.86 \%$ to the medium head type. The classification curve and T.D. strongly resembles that of the adult males of Izumo, Koma, Harima, Yamato, Inaba, and Shinshu-Kami-Ina. The resemblance to the Ainu of Hokkaido and to the people of Etch $\bar{u}$ is negligible.

4) Comparing the Suhō district males with those of other districts according to the M.T.D., those of the Koma, Yamato, Izumo, Harima, Bitchu, East Saitama, and ShinshuIida, reveal a M.T.D. of below 5.50. This is an interesting discovery in view of the fact that the districts just mentioned all retain the history of immigration from the Asian Mainland. On the other hand, the people of Etchũ and Noto who are considered to be of Ainu origin, together with the Ainu of Hokkaido, reveal a M.T.D. of over 12.00, and the relationship is vague.

From the above data the general conclusion can be drawn that the people of Suho district, judging from the measurement results of the various qualities of the highest value in constitutional anthropology, are highly similar to the Yamato, Izumo, Bitchū. and Koma people, descendants of immigrants from the Asian Mainland and who had boasted of the highest form of civillization in Japan, and also to the peoples who held 
active communication with the Asian Mainland. The Suho people had relations with the Yamato dynasty since the era of the tenth Emperor Sujin and went under the leadership of the Yamato dynasty by the time it completed the unification of the country around the middle of the fourth century. They thus were able to prosper, and due to dommunication facilities they probably received the influence of both the Sanyo and San-in sides of the mountainous area, and further by constitutional anthropological study, they show strong racial affiliality to the peoples of Yamato and Izumo. It is also an interesting fact to note that they also show a strong resemblance to the peoples of Bitch $\bar{n}$ and Harima situated along the Sanyo highway.

(From the Department of Hygiene, Nippon Medical College, Tokyo) 